Post-print of Za, Stefano; Spagnoletti, Paolo; Winter, Robert; and Mettler, Tobias (2018) "Exploring Foundations for Using Simulations in IS Research," Communications of the Association for Information Systems, 42(1), 268-300

\title{
EXPLORING FOUNDATIONS FOR USING SIMULATIONS IN IS RESEARCH
}

\author{
Stefano Za \\ LUISS Guido Carli University \\ Italy \\ Robert Winter \\ University of St. Gallen \\ Switzerland
}

\author{
Paolo Spagnoletti \\ LUISS Guido Carli University \\ Italy \\ Tobias Mettler \\ University of Lausanne \\ Switzerland
}

\begin{abstract}
Researchers in many fields have adopted simulation to understand a system's behavior by imitating it through an artificial object that exhibits nearly identical behavior. Although simulation approaches have been widely adopted for theory building in fields such as engineering, computer science, management, and social sciences, researchers in the IS field often overlook their potential. In this paper, we examine how IS research uses different simulation approaches and, thereby, provide insights and methodological recommendations for future studies. From reviewing the literature on simulation studies published in top-tier IS journals, we define three classes of simulations: the self-organizing, the elementary, and the situated. We identify a set of stylized facts for characterizing the ways in which IS simulation studies present the premise, the inference, and the contribution. As a result, we provide guidance to future simulation researchers in designing and presenting their findings.
\end{abstract}

Keywords: Simulation and IS, Compositional Styles, Systems Approach, Information Views, Literature Review. 


\section{Introduction}

Simulation has been adopted in many fields as a means to understand a system's behavior by imitating it through an artificial object that exhibits nearly identical behavior. Simulation has been applied to study physical systems whose behavior can be described by mathematical laws (e.g., differential equations) that allow one to explain and to predict phenomena. In addition to such theory-building capability, simulation approaches are also applied quite commonly in engineering design. Although one can generally understand the behavior of a system's separate components well, validating the fit relationship between the ensemble and its environment is often problematic.

Simulation can help address this issue by providing a means to reproduce the system's behavior in a controlled environment. The availability of powerful computer hardware and advanced artificial intelligence have greatly extended the range of systems whose behavior we can initiate through simulation techniques (Simon, 1996 p. 13) and may span from natural to artificial behaviors and from biological (Keen \& Spain, 1994) to social systems (Gilbert \& Troitzsch, 2005).

Developing and validating theories through simulation must, however, not be restricted to only computational simulations. There is a long tradition of human-based simulations, which have inherently included the "what-might-be" research approach as opposed to or in addition to the "what-is" and "whatshould-be" research approaches (Burton \& Obel, 2011). Simulation studies particularly help one to build a place where one can easily explore new concepts, ideas, boundaries, and limitations and to build predictive and prescriptive theories (Casti, 1997). Previous studies in management have claimed the value of simulations for gaining theoretical insights on the dynamic behavior of complex interactive systems through the development of a formal model together with experimental design (Harrison, Zhiang, Carrol, \& Carley, 2007).

In their roadmap for simulation-based theory building in management studies, Davis, Eisenhardt, and Bingham (2007) define simulation as a method for using computer software to model the operation of "realworld" processes, systems, or events (Law \& Kelton, 1991). One can interpret simulations as virtual experiments (Carley, 2001). According to Davis et al. (2007, p. 481), "simulation involves creating a computational representation of the underlying theoretical logic that links constructs together, and these representations are coded into software that is run repeatedly under varying experimental conditions (e.g., alternative assumptions, varied construct values) in order to obtain results". As result of their research, they identify five simulation approaches: system dynamics, NK fitness landscape, genetic algorithms, cellular automata, and stochastic processes.

Recent studies (Beese, Haki, \& Aier, 2015; Spagnoletti, Za, \& Winter, 2013; Zhang \& Gable, 2014) have emphasized the growing importance of simulation studies both in IS and its reference fields (Grover, Ayyagari, Gokhale, \& Lim, 2006). The emergence of specialized journals such as Computation and Mathematical Organization Theory, Simulation Modelling Practice and Theory, and Journal of Simulation confirm these positive trends. One can explain these trends by referencing the significant advancements in software engineering, artificial intelligence, and the growing amount of data available today that stimulate the development and continuous refinement of simulation methods, tools, and techniques for research purposes (Wooldridge, 2009). Other factors that accelerate the diffusion of simulation include the possibility to easily access to powerful simulation packages and the availability of open source tools made available by simulation research practitioners.

IS design science research considers simulation as one of the experimental design evaluation methods and that focuses on "executing artifact[s] with artificial data" (Hevner, March, Park, \& Ram, 2004; Mettler, Eurich, \& Winter, 2014). Other IS studies use simulation for validating explanatory and predictive theories as recommended by reference fields such as operational research, management science, and artificial intelligence (Barbati, Bruno, \& Genovese, 2012; Davis et al., 2007; Kulik \& Baker, 2008; Lee \& Kim, 2008; Mielczarek \& Uzialko-Mydlikowska, 2010; Za \& Spagnoletti, 2013). Computational simulations and experiments that involve human agents have many similarities, and it is sometimes difficult to distinguish between them given the role that digital tools play in experimental settings. For instance, they both offer the possibility to set up computational laboratories for the study of organizational phenomena through whatmight-be analysis and triangulation among different methods (Burton \& Obel, 2011),

Accordingly, in this paper, we use the term "simulation" to refer to the use, for research purposes, of any artifact (i.e., model, method, instantiation) that imitates the behavior of the system under investigation. With such wide-ranging view, simulation studies can also involve human agents' interacting in experimental settings with or without the mediation of digital tools. 
While some top-tier IS journals have published simulation studies that follow our definition, we can consider simulation studies penetration and impact on the general IS research community secondary if we compare them with other forms of empiric or data-driven research (Zhang \& Gable, 2014). We contend that researchers seem to have little appreciation for simulation-based research for two reasons: on the one hand, IS researchers frequently encounter issues in dealing with the methodological complexities of simulation (Davis et al., 2007; Harrison et al., 2007) and with positioning and defining their simulation studies' knowledge contributions to a larger community of researchers (Zhang \& Gable, 2014); on the other hand, as it happens in other non-dominant research methodologies and perspectives, such as qualitative (Lee \& Baskerville, 2003; Myers, 1999) or design-oriented research (Gregor \& Hevner, 2013), reviewers lack the experience to assess the general knowledge contribution of IS simulation studies for the wider IS research community.

In view of the multiple challenges presented, we examine from an epistemological viewpoint what the concept of simulation as a method means and describe how IS research can use different simulation approaches. In doing so, we provide insights and methodological recommendations for future studies. By describing possible genres of simulation-based research, we may clarify the opportunities that such approaches offer so that reviewers better comprehend their complexity and value to the IS field.

\section{Methodology}

Considering our emphasis on better understanding the actual use of simulation in the broader IS community, we opted for a study with medium systematicity as Rowe (2014, p. 251) describes. Following Rowe's recommendations for conducting bibliographic research, reducing the level of systematicity is legitimate when one focuses on improving the theoretical understanding of a phenomenon or domain (as opposed to describing or explaining) since a broad coverage of topics is more important than an exhaustive search process.

In conducting our review, we followed a well-established approach, which Mayring (2003) designates as an "ideal type" review (cited by Seuring \& Muller (2008) and Rowe (2014)). Typically, such an ideal type review comprises four major steps: 1) collecting material, 2) descriptively analyzing the collected material, 3) selecting structural dimensions and categories based predominantly on theory, and 4) evaluating and interpreting the ultimately selected body of evidence in depth.

Although we adhered to this overall process, which we show in Figure 1, our study differs from an ideal type review in several ways. First, in order to improve our general understanding of the literature that IS simulation studies use, we conducted a thematic analysis to identify possible topical clusters and relations in the literature. Second, since there have been few conceptual discussions related to the use of simulations in IS research so far, the step concerning the theory-driven selection of the literature also comprised our developing a taxonomy as Nickerson, Varshney, and Muntermann, (2013) understand it. We needed such a taxonomy so we could code the collected material in a systematic way. Third, instead of analyzing the body of evidence either from a qualitative or quantitative perspective, we used a mixed-methods approach (Venkatesh, Brown, \& Bala, 2013), which we did to complement our view on the use of IS simulations and to obtain a more complete foundation for deriving compositional styles and identifying exemplary configurations of simulation studies in general IS research. 


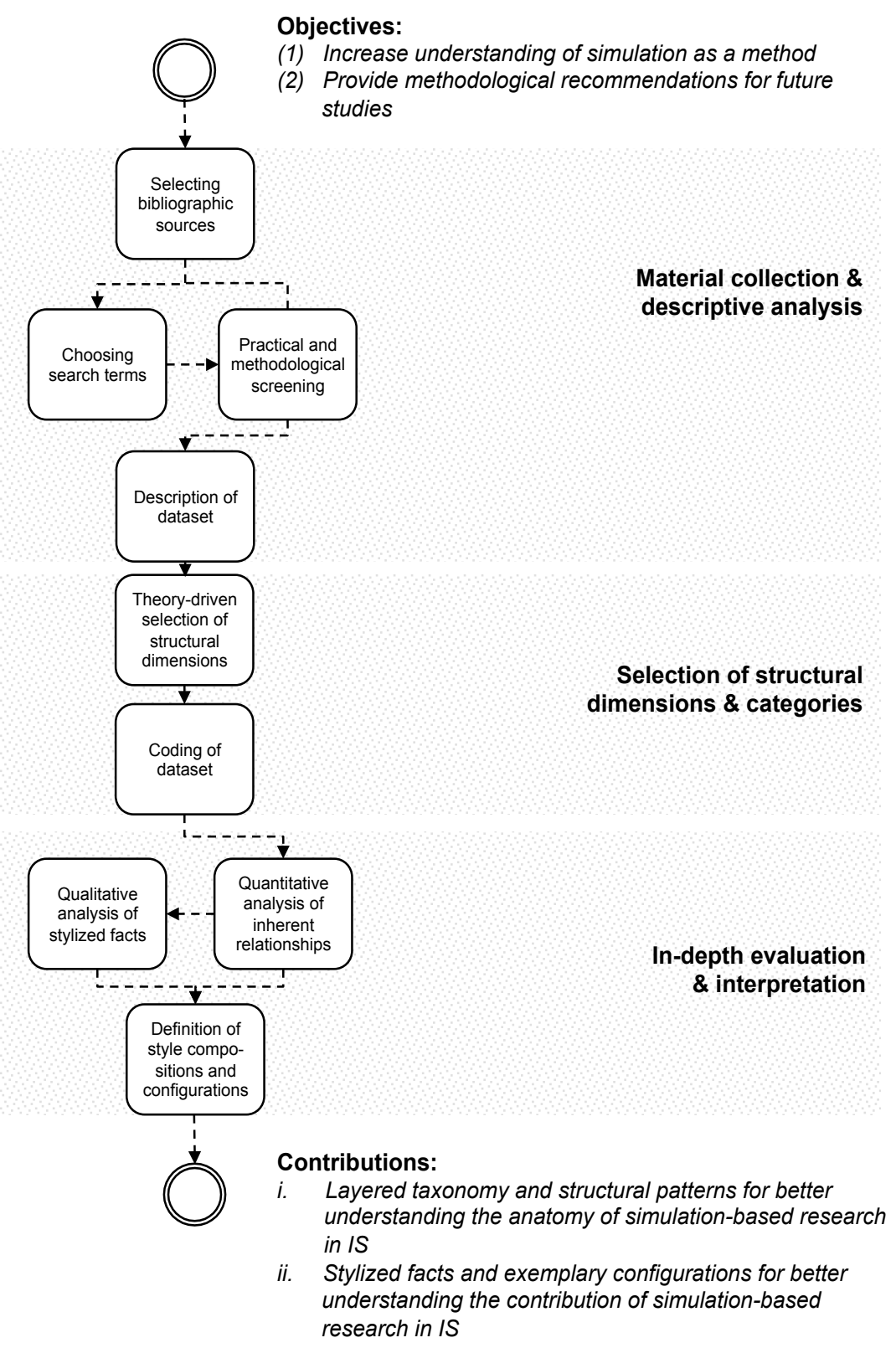

Figure 1. Procedure of our Review for Understanding (Adapted from Mayring 2003)

\subsection{Material Collection and Sample Description}

In a systematic literature review, researchers select a certain number of criteria to select material to be further analyzed. These criteria can pertain to the recognition of the publication outlet in the respective research field, the thematic relevance of the paper to the topic of research (e.g., measured by the appearance of certain keywords in the title, abstract, or the body of the paper), the date it appeared, the number of references to that paper, and so forth.

In order to comprehensively cover the overall simulation literature in the IS field, we conducted a first search in the 21 top- and second-tier IS journals that Lowry et al. (2013) describe. To perform the search, we specified a query on the ISI Web of Knowledge database using the five simulation types that Davis et al. (2007) suggest (i.e., "system dynamics", "NK fitness landscape", "genetic algorithm", "cellular automata", and "stochastic processes") plus the more generic term "simulation" as search terms. We did not use any temporal restriction for the search. 
This first query returned 505 papers published between 1985 and 2013 out of which Decision Support Systems published almost half (238 or 47\%). Other major publication outlets for simulation studies included Information Systems Frontiers with 39 (8\%), Information Systems Research with 32 (6\%), the Journal of Management Information Systems, Journal of Computer Information Systems, and Electronic Commerce Research \& Applications with 24 papers (5\%) each (see Table A1 in the Appendix).

In order to identify a common set of methodological references on which IS simulation studies are grounded, we first explored the dataset by performing a co-citation analysis (Culnan, 1986; Grover et al., 2006), which resulted in no significant relations between referenced papers. In view of our research goals to better understand simulation use and impact on the general IS research community (Bernroider et al., 2013) as well as considering the high number of papers which that"makes a review at best ephemeral if not unachievable" (Rowe, 2014), we restricted our dataset by only selecting papers in top-tier IS journals that applied simulation as principal research method for their investigation (see Table A2 in the Appendix). We also discarded papers that generally reported about simulation, such as tutorials, or studies that focused on the use of simulation in organizational practices (Leonardi, 2013). We discarded these papers after browsing the abstracts and, if necessary, by additionally reading the methodology section of the paper. We discussed discrepancies in judgments until we reached agreement about inclusion or based on the previous principal criterion. In this sense, the major criterion for inclusion was the practical application of simulation as method to address research goals in general IS publication outlets.

As Figure 2 shows, we found 75 papers that were relevant for our purposes. We can see that Information Systems Research (29 papers), the Journal of Management Information Systems, (20 papers), and MIS Quarterly (12 papers) published the majority of the papers.

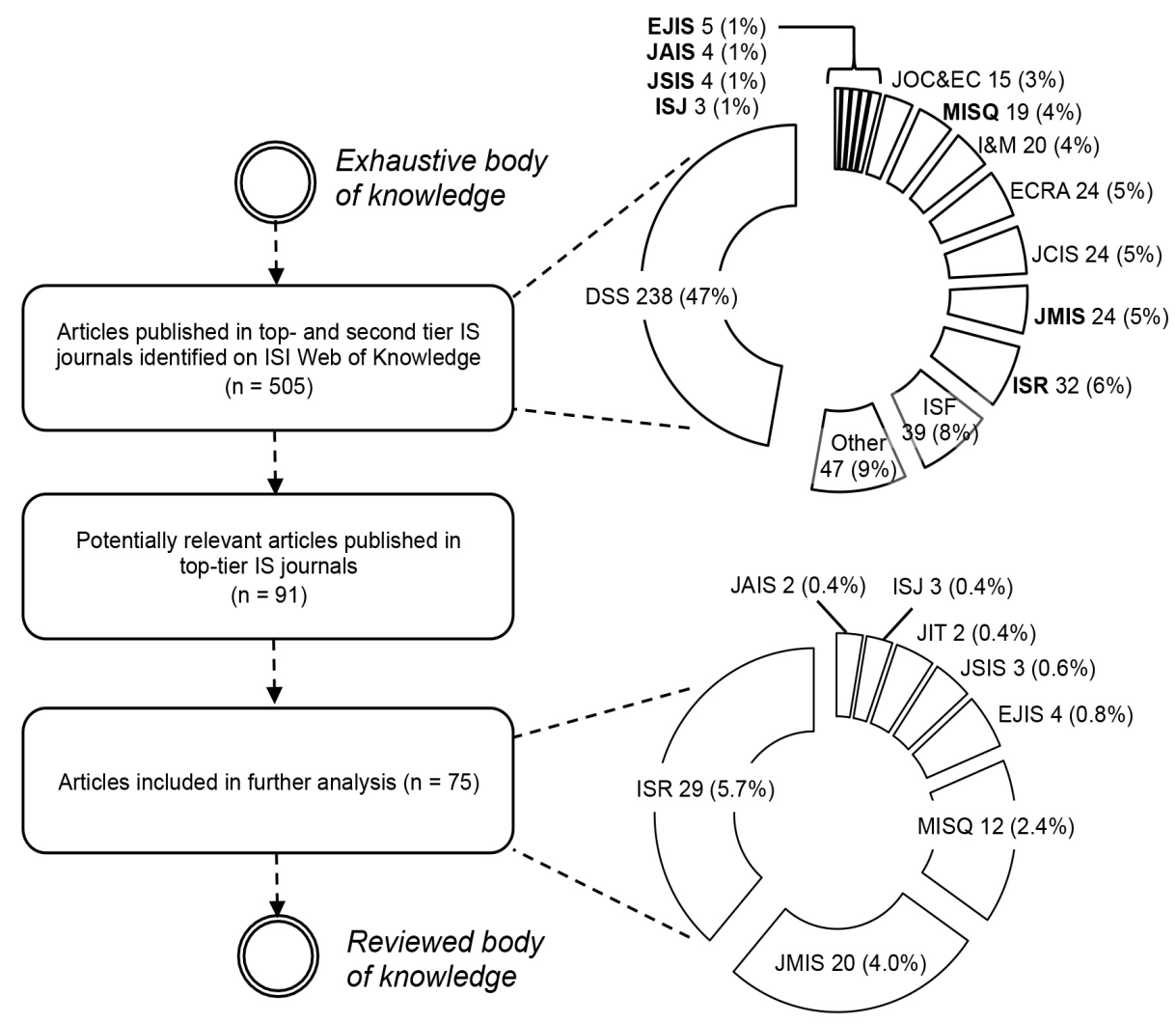

Figure 2. Systematic Selection of Bibliographic Sources for Further Analyses (Brackets Show the Percentage of Papers as to the Initially Identified Body of Knowledge) 


\subsection{Selection of Structural Dimensions and Categories}

Synthesizing the literature involves summarizing numerous research findings (Rowe, 2014) and sometimes creating a new framework for richer explanations or more comprehensive presentations of evidence. However, one should ground the synthetic vision should ground, to some extent, on previous theoretical considerations (Kappos \& Rivard, 2008). Accordingly, we used the five key concepts "information", "system", "theory", "organization", and "relevance" that Allen Lee (2010) adopts in his retrospective and prospective analysis of IS research that a special issue of the Journal of Information Technology published as the basis to delineate our synthetic vision.

Likewise, though addressing a narrower body of knowledge, we find these concepts useful for reflecting on the methodological assumptions of previous IS simulation studies and for opening a debate on the potential role of these studies along the IS research paths that Lee (2010) traces. Therefore, we use them as lenses to understand what theories IS researchers use when they apply simulation methods for developing theoretical knowledge.

Among the five concepts, we selected the three in line with our research goal: information, theory, and organization. We discarded the system and the relevance dimensions. Lee (2010) argues that the presence of systems concepts in much IS research "is, at best, only occasional and not plentiful" and that the label "information technology" can often replace "information system". As a consequence, researchers often neglect the systemic view that should characterize our field. In particular, he points out that researchers need to undertake the major effort of accounting for the ties or interfaces between all parts of information systems. Therefore, looking at the "system" concept as a potential dimension of analysis would result in one's focusing on those studies that link variables in a systemic way.

When we look at simulation methods adopted in management studies, we can easily identify systemic constructs such as parts (i.e., agents, modules, etc.), ties (i.e., interactions, feedback loops, etc.), and levels (i.e., micro- or macro-levels, etc.) that researchers have used to model the phenomenon under investigation. In fact, Burton and Obel (2011) define computational models as "a specification of relations, equations, variables, parameters, rules, procedures, or more generally, algorithms that are computed". Since we build our dataset on a subset of such management studies, we expect all the papers to belong to the category of those that show a systemic view. Therefore, we discard the system dimension of analysis as a straightforward foundation of simulation approaches.

Furthermore, Lee (2010, p. 343) defines relevance as "[a theory's] efficaciousness to managers and others in the 'real world' for the tasks that they need to accomplish". Because we explore foundations of simulation to later propose guidelines that will help IS researchers to choose those (simulation) approaches that best match their respective research questions, our "managers and others in the "real world" are researchers, their task is creating scientific IS knowledge, and efficaciousness means that applying our recommendations as a means needs to be effective in creating desired research outputs as an end. As a consequence, we do not need to differentiate distinct types or classes of simulation-based IS research with regard to relevancy but consider all observed simulation-based IS research as belonging to the same class of relevance; namely, as scientific knowledge contributions in IS.

However, we added a "simulation type" dimension to better comprehend the nature of applied simulation approaches. Table 1 illustrates the categories of the theoretical dimensions for our coding and labeling procedure, which we explain in Sections 2.2.1 to 2.2.4 and summarize their features in Section 2.2.5.

Two co-authors separately performed the coding. In case of discrepancy or incertitude, the two researchers consulted the entire author team and discussed the coding with them until we all reached agreement.

\subsubsection{Simulation Type Dimension}

Following Davis et al. (2007), a major category is analytical simulations (AN), which we can categorize as mathematical models for simulating some specific phenomena. These studies focus on using formal models and complex equations that cannot be solved analytically (e.g., game theory, algorithms designed ad hoc) to determine the optimal value of some variables under varying conditions.

So-called system dynamics (SD) approaches build another stream of simulation methods. IS studies in this subset explicitly refer to the view of a system as comprising processes that have some common constructs and, hence, that interact in a set of circular causal loops (Sterman, 2001). These causal loops can be positive or negative depending on the characteristics of the feedbacks. 
Table 1. Theoretical Dimensions

\begin{tabular}{|c|c|c|}
\hline Dimension & Values & Distinguishing attributes \\
\hline \multirow{4}{*}{ Simulation type } & Analytical & $\begin{array}{l}\text { Mathematical models for simulating specific phenomena (Davis et al., } \\
\text { 2007) }\end{array}$ \\
\hline & System dynamics & $\begin{array}{l}\text { Processes that comprise common constructs that interact in a set of circular } \\
\text { causal loops (Sterman, 2001) }\end{array}$ \\
\hline & Agent based & $\begin{array}{l}\text { Automated agents are used to populate an artificial world and simulate the } \\
\text { behavior of their real-world counterparts usually to test theoretical and } \\
\text { empirical constructs (Druckenmiller \& Acar, 2009) }\end{array}$ \\
\hline & Human based & $\begin{array}{l}\text { Experiments that test the effects of different conditions by adhering to the } \\
\text { principles of control, randomization, and manipulation (Mettler et al., } \\
\text { 2014) }\end{array}$ \\
\hline \multirow{5}{*}{$\begin{array}{l}\text { Theory } \\
\text { contribution } \\
\text { (Gregor, 2006) }\end{array}$} & Analyzing & $\begin{array}{l}\text { Says what is. The theory does not extend beyond analysis and description. } \\
\text { No causal relationships among phenomena are specified and no predictions } \\
\text { are made. }\end{array}$ \\
\hline & Explaining & $\begin{array}{l}\text { Says what is, how, why, when, and where. The theory provides explanations } \\
\text { but does not predict with any precision. There are no testable propositions. }\end{array}$ \\
\hline & Predicting & $\begin{array}{l}\text { Says what is and what will be. The theory provides predictions and has } \\
\text { testable propositions but does not have well-developed justificatory causal } \\
\text { explanations. }\end{array}$ \\
\hline & $\begin{array}{l}\text { Explaining and } \\
\text { predicting }\end{array}$ & $\begin{array}{l}\text { Says what is, how, why, when, where, and what will be. Provides predictions } \\
\text { and has both testable propositions and causal explanations. }\end{array}$ \\
\hline & Design and action & $\begin{array}{l}\text { Says how to do something. The theory gives explicit prescriptions (e.g., } \\
\text { methods, techniques, principles of form and function) for constructing an } \\
\text { artifact. }\end{array}$ \\
\hline \multirow{3}{*}{$\begin{array}{l}\text { Research domain } \\
\text { (Lee, 2010) }\end{array}$} & IT Artifact & $\begin{array}{l}\text { Referred to the technical part of an IS phenomenon. Focused on evaluating } \\
\text { an IT artifact's performance. }\end{array}$ \\
\hline & $\begin{array}{l}\text { Individual } \\
\text { behavior }\end{array}$ & $\begin{array}{l}\text { Focused on understanding structural and agency aspects of individual } \\
\text { behavior, in accordance with Lee's (2010) definitions of methodological } \\
\text { individualism. }\end{array}$ \\
\hline & $\begin{array}{l}\text { Organizational } \\
\text { behavior }\end{array}$ & $\begin{array}{l}\text { Focused on understanding structural and agency aspects of organizational } \\
\text { behavior, in accordance with Lee's (2010) definitions of methodological } \\
\text { holism. }\end{array}$ \\
\hline \multirow{4}{*}{$\begin{array}{l}\text { Information view } \\
\text { (McKinney \& Yoos, } \\
\text { 2010) }\end{array}$} & Token & $\begin{array}{l}\text { Information and data are both tokens manipulated by processes (e.g., } \\
\text { memory chunking, processing a transaction, summing transactions). }\end{array}$ \\
\hline & Syntax & $\begin{array}{l}\text { Information is the measurable relationship among tokens that reduces } \\
\text { entropy (e.g., the rings in a tree, a hash function). }\end{array}$ \\
\hline & Representation & $\begin{array}{l}\text { Information is meaning that emerges from a sign that stands for an object } \\
\text { to a particular observer (e.g., a solar eclipse, a database that represents } \\
\text { transactions). }\end{array}$ \\
\hline & Adaptation & $\begin{array}{l}\text { Subjectivist assumptions are introduced to explain how a system creates } \\
\text { information. Information is created when a system perceives differences in } \\
\text { its environment that alter that system, causing its adaptation (e.g., } \\
\text { interpretation of this paper, recursive programming). }\end{array}$ \\
\hline
\end{tabular}

To obtain a sufficient and reasonable number per group, we had to merge Davis' et al. (2007) initially defined categories NK fitness landscape, genetic algorithm, and cellular automata into one category named agent-based (AG) simulations. Agent-based simulations are able to model a real scenario creating artificial worlds. . One uses automated agents to populate these worlds and simulate the behavior of their real-world counterparts usually to test theoretical and empirical constructs (Druckenmiller \& Acar, 2009). In general, one describes an AG model through a set of parameters that characterize the environment in which the agents act and a set of more or less complex functionalities (behavior) and attributes (the internal states) of an agent. The agent state can be also based on its cognitive perception (real or believed) of reality (i.e., beliefs, trust, dependence). One can consider cellular automata, genetic algorithms, and NK fitness landscape as specific cases of agent-based simulations. 
Cellular automata (CA) represent dynamic systems where space and time are discrete. CA are usually based on a set of cells (seen as agents) with a finite number of possible states. Based on a common local transition rule, every cell updates its state synchronously with the others (Verel, Collard, Tomassini, \& Vanneschi, 2007). NK fitness landscape is a specific case of CA (Allen \& Varga, 2006) in which each agent looks for a better position on the fitness improvement landscape and compares at every round its fitness level with the nearest ones while always adopting the highest. The agent stops its searching once it reaches a suboptimal peak. Usually $\mathrm{N}$ is the number of the agents in the system and $\mathrm{K}$ indicates the number of connections, also known as network density (Curşeu, 2006; Yuan \& McKelvey, 2004).

Genetic algorithms are a computational scheme derived by cellular automata (Nguyen, 2005). In genetic algorithms (GA) simulation, agents have a common goal and focus on achieving a near-optimal solution for modest-sized problem. Among the possible GA parameters is usually the number (static or dynamic) of candidate solutions at each step and diversity in those alternatives (Fazlollahi \& Vahidov, 2001).

The AG simulation approaches share the common assumption that IS phenomena emerge from the interaction among agents or modules and cannot be predicted from the characteristics of the single agents or from the rules of their interaction.

A fourth category of simulations is human-based (HU) simulations. In these studies, groups of people participate in role-playing in which they interact in a simulated world (e.g., business game). HU simulations are also referred to as experiments that test the effects of different conditions by adhering to the principles of control, randomization, and manipulation (Mettler et al., 2014). The use of HU simulation is common when the behavior of an agent becomes too complex for one to embed it into the artificial agent's cognitive model. Though a key characteristic of HU simulation involves engaging human actors in a controlled experiment, one can adopt artificial agents to populate the environment in which the individuals act. Some papers use HU simulation as an evaluation method in designing an IT artifact (Mettler et al., 2014).

\subsubsection{Theory Contribution Dimension}

The second dimension for our subsequent analysis relates to the nature of the theory contribution of IS simulation studies. Given we focus on exploring how researchers have successfully used simulation approaches for research purposes in the IS domain, we need to understand if there are any relationships between simulation approaches and the nature of knowledge generated through simulation.

We follow Lee's (2010) choice of adopting the classification of theory types that Gregor (2006) proposes. Researchers across the IS community have widely accepted this classification, which classifies theories into five types: theory for analyzing, theory for explaining, theory for predicting, theory for explaining and predicting, and theory for design and action. Analytic theories focus on what an IS phenomenon is without explaining causality or attempting predictive generalizations. Classification schemas, frameworks, or taxonomies are typical contributions of such kind of theories. The second type of theory explains primarily how and why phenomena occur. It often leads to a process-type theory and focuses on better understanding the IS phenomenon instead of predicting it with any precision. As third type of theory, theories for predicting, say what will be but not why. Therefore the interactions and connections among and systems parts and variables remain a "black box". In contrast, theories for explaining and predicting (fourth type) say how, why, and when an IS phenomenon will occur, which implies both an understanding of underlying causes and prediction as well as a description of theoretical constructs and the relationships among them. The fifth type, theories for design and action, gives explicit prescriptions for constructing an IT artifact intended as representational constructs, models, methods, and instantiations (March \& Smith, 1995). These theories focus on principles of form and function, methods, and justificatory theoretical knowledge that are used in the development of IS (Gregor \& Jones, 2007).

\subsubsection{Research Domain Dimension}

The third dimension for our subsequent analysis relates to the organization concept. Lee (2010) argues that the scope of IS research should be the organizational and not just the technological aspects of an IS phenomenon. However, research in IS has monolithically used the term "organization" to refer to any and all people-related things. In fact, when focused on social phenomena, IS research is characterized by methodological individualism and, therefore, fails to cover the non-individual phenomena that IS researchers encounter in the interactions between organizations and technology. Lee suggests to change the focus of IS research by looking at an organization as a system in which both structural dimensions and individual-level behavior contribute to determine observed social regularities. 
Given this conceptualization, we investigate whether simulation studies apply to both organizational and technological aspects of IS phenomena and which are the methodological foundations of each approach. We address these issues by analyzing the research domains of successful simulation studies and by looking for regularities in the association between simulation approaches and research domains.

In order to identify a useful research domain classification for our analysis, we first refer to the common sense distinction between the technical and the social parts of an IS phenomenon. Therefore, we distinguish those papers that use simulation to evaluate the performance of an IT artifact from those that focused on understanding structural and agency aspects of social behavior. When a paper addresses social behavior, we borrow Lee's (2010) definitions of methodological individualism and methodological holism for characterizing individual behavior and organizational behavior, respectively.

By doing so, we address the issue of classifying research domains in IS in a way that is general enough but also specific with respect to our research purpose. In fact, although researchers widely recognize levels of analysis as a possible means for classifying IS phenomena, few approaches mix the artifact level with the social level. For instance, in their attempt to understand and optimize IS success/value, Kolfschoten and de Vreede (2009) overlook the IT artifact and refer to only individual IT use, group IT use, and process IT use. Similarly, Mitra, Sambamurthy, and Westerman (2011) differentiate individual usage effects, business process effects, and business unit effects for measuring IT performance and communicating value but neglect the IT artifact role. In contrast to these approaches, our coding of the organizational dimension includes the IT artifact, the individual, and the organizational behavior by borrowing concepts from more general taxonomies (Niederman, Davis, Greiner, Wynn, \& York, 2006).

\subsubsection{Information View Dimension}

Lastly, another important dimension we need to consider in our analysis of simulation studies concerns the concept of "information". In particular, we investigate whether and how a given simulation approach implies some assumptions on what information means. Since the IS phenomenon refers to the behavior of an information processing system, the ways in which a researcher views information has many methodological and philosophical implications (Delanda, 2011).

Also, in this case, we follow Lee (2010) by adopting the four views of information as Mckinney and Yoos (2010) define. This taxonomy distinguishes four views of information: token, syntax, representational, and adaptation. In the token view, information and data are tokens without profound meaning or structure (just zeros and ones). Information can be input or output of a process (such as posting a purchase transaction record to a database that involves a sequence of processes to record the purchase, validate it, code it, store it in memory, and retrieve it for subsequent analysis).

In the syntax view, information still has no meaning but has structure, which reduces entropy (e.g., rings in a tree, a hash function). In this view, the distinguishing characteristic is the measurability (e.g., the measure of the relationship between two passwords could be their equality). In the representation view, information has both structure and meaning, which emerges from a sign that stands for an object to a particular observer (e.g., a solar eclipse, a database that represents transactions). Finally, in the adaptation view, information has structure, meaning, and a historic background that explains how the system generates it (e.g., interpretation of this paper, recursive programming). Researchers have advocated a shift toward an adaptation view of information as a desirable direction for developing research in the IS field (Lee, 2010).

We note that, despite our borrowing the definitions of the four views of information, the classification results we obtained by coding simulation papers with these categories differ in general from those that Mckinney and Yoos (2010) obtained in building their taxonomy. In fact, the two coding procedures have different purposes and, therefore, lead to different results. While McKinney and Yoos (2010) focus on understanding how authors of selected papers interpret the information concept in the empirical IS phenomenon under investigation, we focus on how information is conceived in the simulated system.

\subsubsection{Dimensions Features}

As we describe above, we adopted four dimensions to build our classification: simulation type, theory contribution, research domain, and information view. Using a deductive approach, we identified each dimension and its values through a logical process derived from theories and conceptualizations while (Nickerson et al., 2013). In our coding, each paper has exactly one value for each dimension. This configuration ensures the mutual exclusiveness (no paper can have two different values for the same dimension) and the collective exhaustiveness (each paper needs to have one of the possible value for each dimension) (Nickerson et al., 2013). 
Moreover, the number of dimensions with their values differentiates each paper-or cluster of papers-for our purposes here. Likewise, the limited number of dimensions makes it easier to comprehend and apply the coding schema. The dimensions are also sufficient for classifying all papers in our dataset and allow the possibility to include other dimensions in the future. Finally, each dimension is useful to explain the nature of each paper. These dimensional features make the coding robust, concise, comprehensive (based on its completeness), extendible, and explanatory (Nickerson et al., 2013).

\section{Preliminary Evaluation}

In this section, we report the findings from our preliminary interpretation of the coded body of knowledge. As part of this analysis, we compare the previously identified theoretical dimensions to understand how IS research applies simulation in general and what kind of contributions and assumptions these studies convey.

\subsection{Simulation Type vs. Theory Contribution}

By looking at the distribution of simulation approaches along theory contribution types, we note that simulation types $\mathrm{AG}, \mathrm{AN}, \mathrm{HU}$, and SD contribute to explanatory or predictive theory building and to design theory building.

As Figure 3 shows, we could not clearly assign some of the papers to one of the mentioned simulation types (i.e., "n.a." row). These studies use statistical simulations frequently based on random process models, such as Markov chains or Poisson point processes. These kinds of simulations rarely support explanation because they require existing explanatory knowledge to run them. Nevertheless, some limited amount of explanation becomes possible when one identifies patterns of behavior in stochastically generated data. For instance, Oh and Lucas (2006) found that, in online computer markets, small price increases occur more frequently than decreases, while the frequency of price adjustment is significantly associated with a product's price dispersion.

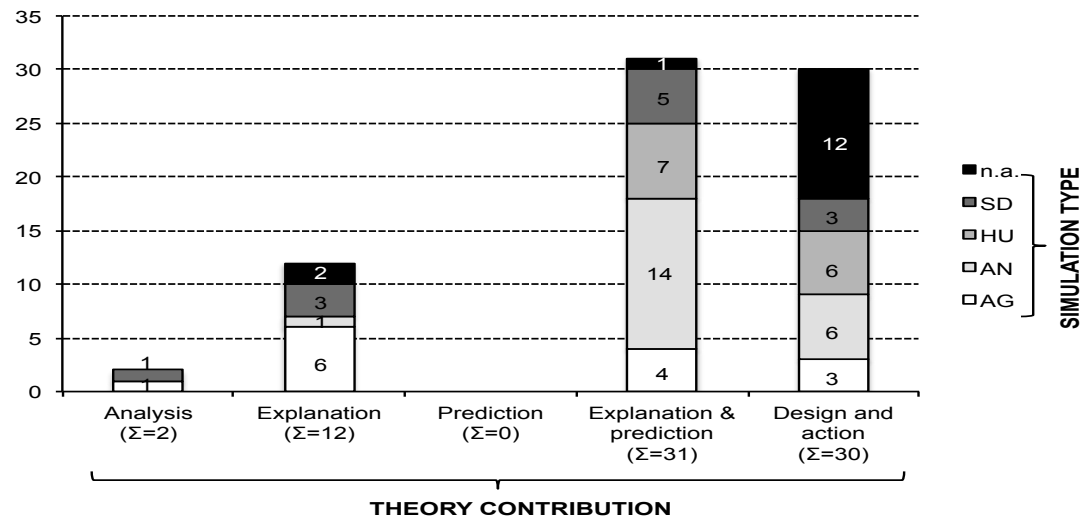

Figure 3. Simulation Type vs. Theory Contribution

Twelve out of fifteen papers in the "n.a." category refer to the design and improvement of some data-analysis technique through statistical simulations such as Monte Carlo (e.g., Qureshi \& Compeau, 2009). One can apply data-analysis techniques, which these papers study, to many research domains with different information views. As such, we discarded these papers from the following steps of our qualitative analysis.

Our results recall the twofold value of simulation that Simon (1996) proposes. Simulation studies allow one to analyze the behavior of an imitated system and to add explanatory and predictive knowledge on the behavior of the real-world system. Furthermore, being grounded in the engineering tradition, all categories of simulation studies play an important role as a powerful tool for defining what-might-be scenarios and, hence, as an evaluation technique in design and action research.

Finally, we note that AG simulation, although used for explanation and explanation and prediction, seems to have a special focus on explanation rather than prediction. To potentially explain this finding, we might note that, as opposed to other simulation approaches, one can ground some AG models in different epistemological assumptions, which is the case, for example, with models grounded in complex adaptive systems (CAS) theory (Curşeu, 2006; Nan, 2011). Such models focus on the emergence of patterns of agents' 
interactions that provides insights for understanding collective behaviors (Raghu, Jayaraman, \& Rao, 2004a; Rao, Chaudhury, \& Chakka, 1995) instead of defining some predictive rule. The validation issue is another reason for the explanatory nature of agent-based simulation. In order to use AG for prediction, one has to validate the model further. The amount of effort required by such validation is often prohibitive. Therefore, most AG studies chose to stay on the explanatory level.

\subsection{Simulation Type vs. Research Domain}

In Figure 4, we outline the results of classifying IS simulation approaches into the categories of the research domain taxonomy. As one can see, AG simulations are clearly related to individual behavior and AN simulations are related less to individual behavior. HU and AG simulations focus on behavior rather than on artifacts. For instance, Dawande, Johar, Kumar, and Mookerjee, (2008) apply an agent-based model to simulate the dynamics of pair development in software projects and to compare performances of solo and mixed development. In contrast, AN simulation studies mostly focus on the IT artifact such as the case of the Mookerjee, and Mannino, and Gilson (1995), who focus on improving the performance stability of inductive expert systems under input noise, or Datta, Dutta, Liang, and VanderMeer (2012), who focus on SOA performance enhancement through XML fragment caching. Wong, Ray, Stephens, and Lewis (2012) apply the artificial immune systems principles to credit card fraud detection and provide an example of how one can adopt an AG simulation approach to assess an IT artifact's validity. Finally, SD simulations are distributed among the three research domains with a particular focus on organizational behavior and facilitate the representation of both quantifiable and hard-to-measure variables (Choi, Nazareth, \& Jain, 2010).

This evidence is consistent with the Lee's (2010) argument that methodological individualism characterizes IS studies, but the four categories of studies considered so far also address the organizational behavior research domain. Potentially, a further look into these papers can provide examples on how to address the methodological individualism versus methodological holism debate.

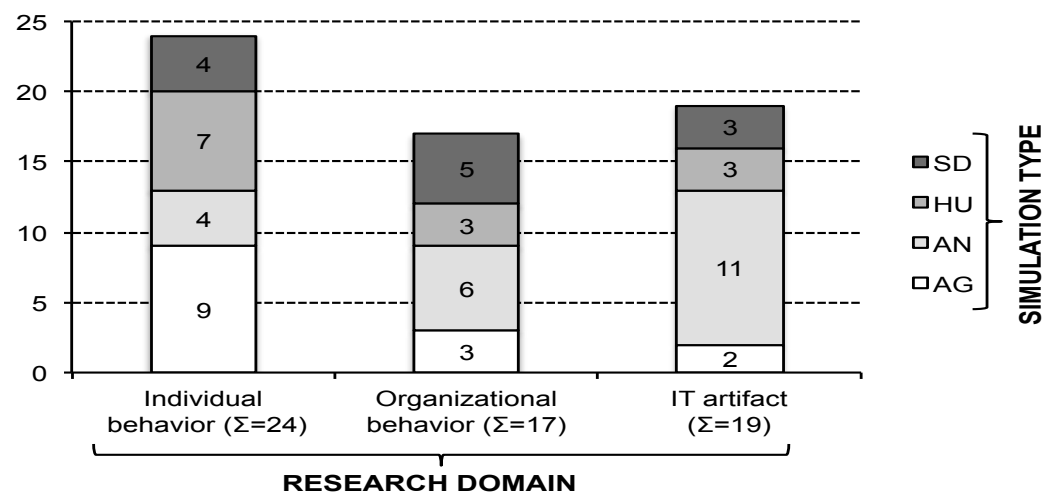

Figure 4. Simulation Types vs. Research Domain

\subsection{Simulation Type vs. Information Views}

The results of the analysis along the information view dimension, as Figure 5 illustrates, show that none of the simulation studies from our sample adopts a token view of information. According to McKinney and Yoos (2010), the token view of information is synonymous with data manipulated by processes without any particular relations among the bits (syntax). Moreover, this view does not include information on how a bit represents an object to an observer (representation), nor how a bit alters the system. As for why, we note that, in a simulation study in which one imitates the behavior of an IS phenomenon through an artificial system, one will not likely simply process information without any relations that can either be an analytical function (i.e., AN), an information flow (SD), an information exchange (AG), or a knowledge interpretation (HU). Therefore, simulation seems to be a good candidate for enlarging the scope of IS studies as Lee (2010) suggests. Furthermore, we can see an information system as being in a continuous state of emergence from the interactions among its three constituent subsystems: the technology system, the organization system, and the data system. In such a view of IS phenomena, the interactions continuously transform the data into what the syntax, representation, or adaptation views would consider to be information (Lee, 2010). 


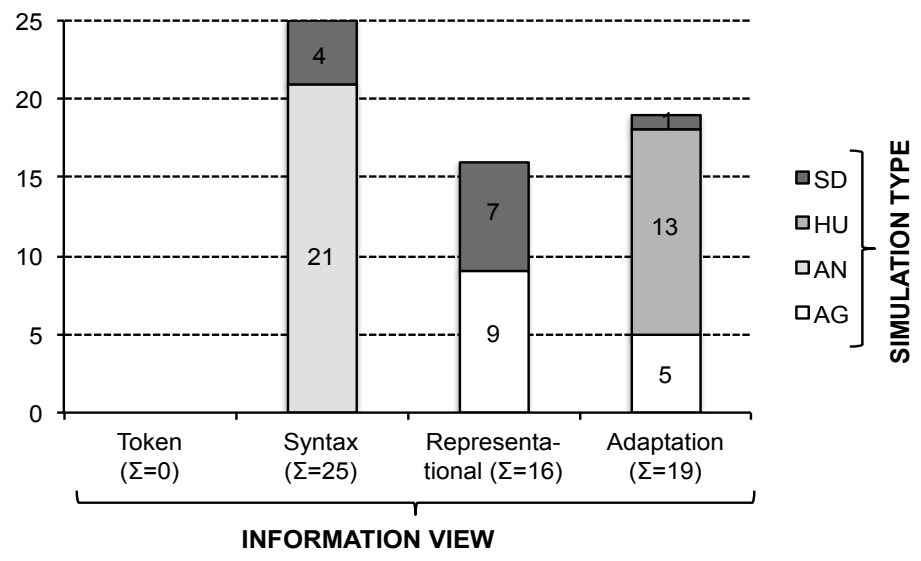

Figure 5. Simulation Types vs. Information View

The analysis also shows that AN simulations adopt a syntax view of information. Sen et al. (2009) provide a good example: they link data such as demand fluctuations and user preferences to maximize participants' organizational welfare in order to propose a mechanism for SLA formulation for IT infrastructure services.

SD simulations mostly adopt a representational view of information. In fact, system dynamics models are based on the representation of flows, stocks, and feedback loops, which universally and objectively have the same meaning for any observer. Such is the case, for example, for the planning model for network services that Dutta (2001) proposes in which he links in a circular way business performance, the size of a provider's customer base, the price of online services, and the network performance. In some cases, SD simulations adopt a syntax view of information. Through discrete events simulation, SD studies can bridge the gap between AN and other simulation studies (e.g., Konana, Gupta, \& Whinston, 2000).

In our sample, HU simulations adopt an adaptation view of information. This finding does not need any further explanation since researchers use human-based simulation approaches when they consider the complexity of human decision making together with the rules of the game that reproduce the system. For instance, Wastell (1996) uses a rich simulation (a "microworld") to gain insights into the human-machine dynamics in digitally supported work environments.

AG simulation exposes a dual character with respect to the information view dimension. It can either adopt representational view or an adaptation view depending on how one views the cognitive model of agents' minds. When adopting a representation view, AG models assume that agents strategically act in their environment by processing some objective and universal information, which is the case, for example, in bidders' behavior in online auctions as modeled by Bapna, Goes, and Gupta (2003). On the contrary, when agents also behave in accordance with how they subjectively perceive some real-world representation, AG models fall into the adaptation view of information and promise to solve many limitations of HU models for understanding complex phenomena. For example, one can see as much in how Curşeu (2006) represents team cognition, trust, cohesion, and conflict: the author describes them as emerging states in interacting agents whose collective behavior impacts the virtual team's effectiveness and, at the same time, is influenced by the virtual team's outcomes (Curşeu, 2006).

\subsection{Implications from Preliminary Evaluation}

From preliminarily analyzing the 75 selected papers, we identify several important findings. First, the papers used all simulation approaches to contribute all types of theory, and they mostly used agent-based simulation approaches in the context of explanatory theory. Second, while the papers applied agent- and human-based simulations mostly to explain individual or organizational behavior, they usually applied analytical simulations to analyze or design IT artifacts. The papers most commonly used system dynamics as their simulation technique to address individual and organizational behavior and IT artifacts. Third, we observed the strongest dependencies when we related simulation types to the dominant information view. Analytical and human-based simulations clearly assumed the syntax and adaptation view of information, respectively. System dynamics simulations assumed a representation view of information, but we also found cases that espoused syntax and adaptation views. Finally, agent-based simulations focused on a representation view, while few studies assumed the adaptation view of information. 
Since we observed the strongest relationship between simulation approaches and the information view, we now elaborate on this discovery. Allen and Varga (2006) argue that the analysis of IS can be characterized by successive simplifications that lead to an increasing reduction of emergence and individual perceptions of IS. By transforming the representation of reality into evolutionary models, then into self-organizing models, then into deterministic systems, and finally into equilibrium models, one stepwise reduces complexity but successively adds constraints (such as classification, averages, equilibrium). Since McKinney and Yoos (2010) understand their proposed taxonomy of information views in pieces of IS research as a layered system rather than a system of independent classes, we can interpret the common use of simulation approaches in the context of IS research as a layered system.

Figure 6 illustrates the resulting, layered taxonomy of simulation approaches based on the information view according to McKinney and Yoos (2010). One can interpret it follows: all simulations go beyond the token view of information because a researcher must sufficiently understand at least information syntax to apply them. While analytical simulations realize only this level of information understanding, other simulation approaches go one or two steps further. System dynamics realize the syntax, representation, and, in one case (Curşeu, 2006), the adaptation view of information. Agent-based simulations assume either a representation or an adaptation view, while all human-based simulations are positioned on the top layer (i.e., realize the adaptation view of information). If we can interpret information views as a layered system of increasing levels of understanding and expressive power, we can likewise relate simulation approaches to these layers. system.

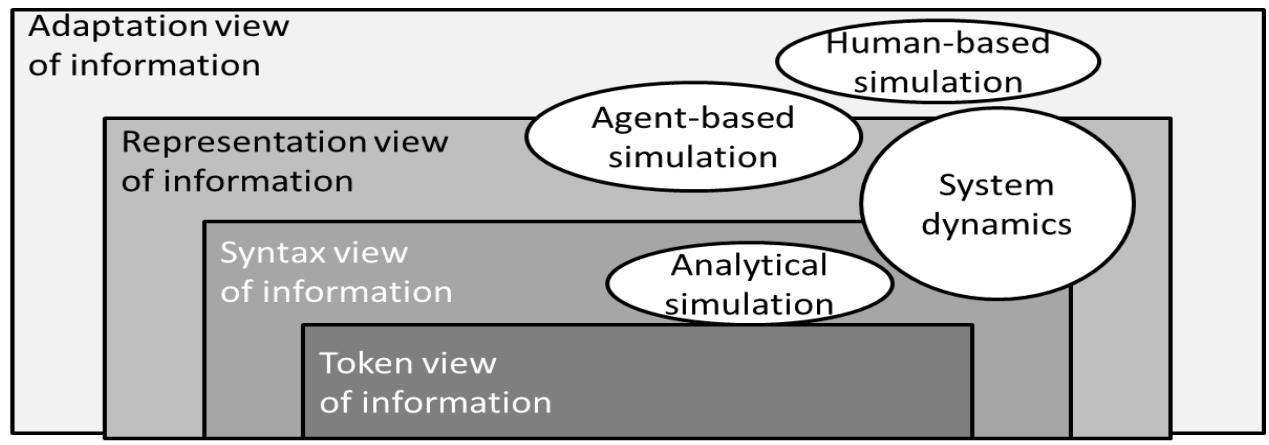

Figure 6. Simulation Approaches Correspond to Information View Layers

\section{Quantitative Analysis of Inherent Relationships}

Before this section, we assume that the four dimensions we identified (i.e., simulation type, information view, research domain, and theory contribution) independently explain different perspectives on the extant IS literature about simulation. While we allude to certain interdependencies in the prior sections, we now focus on determining associations among these preconceived notions by conducting a cluster analysis. One typically performs a cluster analysis as an alternative approach to identify meaningful "groups of references" that indicate shared philosophical assumptions in a field. Thus, by performing a cluster analysis, we can better understand possible streams or subdivisions of simulation-based research in IS. In this sense, we perform the quantitative analysis to corroborate previous observations in the dataset and to provide a complementing perspective for interpreting the use and impact of current simulation studies in more general IS publication outlets.

In conducting our cluster analysis, we followed the guidelines of Balijepally, Mangalaraj, and Iyengar (2011), who propose to make explicit the following four elements of a cluster analysis:

1) Clustering variables: the variables selected for describing the objects being grouped should emanate from past research or explicit theory and be consistent with the study's objectives. As input variables for our clustering, we used the previously identified theoretical dimensions with standardized scales (i.e., simulation type, theory contribution, research domain, and information view).

2) Clustering algorithm and similarity measures: clustering methods range from largely hierarchical procedures (Ward, 1963) to more relocation-based, iterative partitioning strategies (MacQueen, 1965). Balijepally et al. (2011) does not specify clear guidelines for when to use which algorithm. To get an understanding of the inherent limitations of distinct hierarchical or 
non-hierarchical clustering algorithms, we applied various clustering algorithms and measures for estimating the resemblance between the entities being clustered and compared the resulting cluster solutions in view of their interpretability and comprehensibility. We found that we attained a theoretically robust solution when we used a hierarchical clustering with an average linkage criterion and Euclidean distance measures. We found only minimal deviances when using other linkage measures (e.g., median, average, or centroid linkage).

3) Number of clusters: different measures, such as the agglomeration coefficient or the cubic clustering criterion, for specifying the number of clusters exist. Research recommends that one should apply practical judgment, common sense, or theoretical foundations when defining the final cluster solution. In our case, instead of purely relying on statistical coefficients, we used graphical plotting (dendrogram), which Figure 7 illustrates. From analyzing the figure, we can clearly differentiate three clusters.

4) Validation of clusters: we verified the reliability of the cluster solution by assessing the stability of clusters using multiple algorithms (Ketchen \& Shook, 1996) and by splitting the sample in order to check for stability (Punj \& Stewart, 1983). All calculations indicated a reliable cluster solution that comprised at least two clusters. Since a cluster analysis is always a matter of interpretation, we opted for a three-cluster solution because it provided a richer basis for subsequent theorizing and discussion, which we detail next.

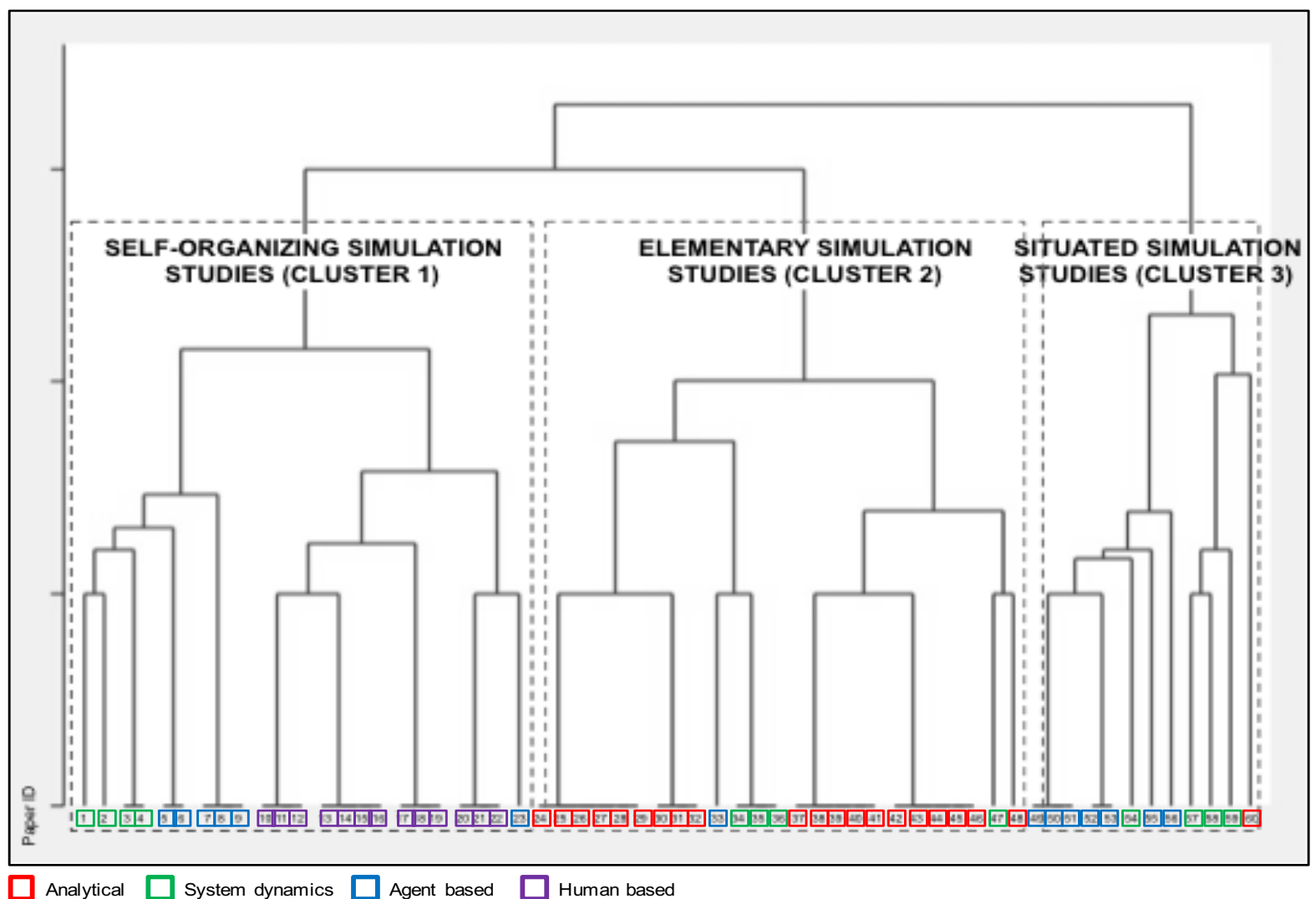

Figure 7. Three-cluster Solution Resulting from the Cluster Analysis (Numbers at the Bottom Refer to the Publication ID as Listed in Table A2 of the Appendix)

The first cluster comprises 23 papers that mostly use HU and AG as means to investigate complex individual or organizational behavior. From an information view perspective, the papers use either an adaptation or a representational conceptualization. In terms of the theoretical contribution, papers in this cluster focus either on explaining and predicting systems' behavior or on developing theories for design and action. We name this cluster "self-organizing" to emphasize the complex interactions that characterize the simulation model.

Most of the simulation studies in the second cluster apply a syntax view on information in order to explain and predict simplified organizational behavior or to inform the basic design and action of IT artifacts. This 
cluster comprises 25 papers out of which AN models represent the bigger and SD models the smaller proportion of IS simulation studies. We name this cluster "elementary" to emphasize the simplifications made to represent the reality in the simulation model.

The third and smallest cluster comprises 12 papers that focus on exploring and analyzing systems' behavior. To do so, these papers mainly use AG and SD models, though they emphasize the information view to varying degrees. This cluster differs from the others because its theoretical contribution centers more on describing phenomena and analyzing observable relationships than on explaining, predicting, and prescribing systems' behavior and design. We name this cluster "situated" to reflect the pragmatic orientation of these studies.

Overall, the cluster analysis provides a comprehensive overview of a "similar" body of knowledge. While, for example, papers in the self-organizing cluster delve into complex systems' behavior, we found that papers in the elementary cluster focus more on simplistic representations of the organizational behavior.

Overall, our results can help researchers conduct their own simulation studies and to find reference studies to base their work on.

\section{Qualitative Analysis of Stylized Facts}

As a final stage of our systematic literature review, we examine in detail the ways in which authors structure their arguments in each cluster of papers. We do so to understand the anatomy of simulation studies in IS journals. In order to identify interesting patterns in our data, we analyze the 60 manuscripts in depth by abstracting from the text some stylized facts in the form of structural patterns and configurations that characterize the ways in which researchers have designed and presented simulation studies in the IS field. We refer to the notion of style composition (Mathiassen, Chiasson, \& Germonprez, 2012) as a means to identify stylized facts and, hence, to obtain a simplified representation of the complex relationships between classes of simulation papers and their research goals, contributions, and presentation styles.

Researchers have used style composition to assess other classes of publications in IS. In their analysis of action research studies, Mathiassen et al. (2012, p. 347) refer to compositional style as "the activity through which authors select, emphasize, and present elements of their research to establish premises, develop inferences, and present contributions in publications". Drawing on this definition and on the analysis of our restricted set of papers, we identify specific styles related to the premises, the inference, and the contribution of simulation studies in IS. The premise style can be either theoretical or practical depending on the focus on previous works or managerial problems, respectively. The inference style is related to the role of prior evidence in simulation studies. On the one hand, model building may be driven by assumptions derived from the extant literature base. On the other hand, model building may rather be motivated by and inferred from observations in the domain of work (Harrison et al., 2007). Finally, the contribution style is related to the outcome of the research process. It can be oriented to theory development, the artifact that embeds the model, and pragmatic experimentation.

Papers in the self-organizing cluster mainly focus on explaining and predicting the adaptive behavior of human agents who interact with IT systems (Chung, Chen, \& Nunamaker, 2005; Wastell, 1996), team members (Kanawattanachai \& Yoo, 2002, 2007), and online market places (Bapna et al., 2003; Greenwald, Kannan, \& Krishnan, 2009; Rafaeli \& Noy, 2002). The premise style is theoretical for most of the studies related to online auctions and virtual teams, while the remaining papers privilege a practical premise style. The inference style is mostly literature based with some exceptions in which the simulation model development is based on field interview data (Abdel-Hamid, 1988). Finally, the contribution style embraces different styles such as artifacts' embedding the simulation model, theoretical development via controlled experiments, and pragmatic experimentation in which different strategies are comparatively analyzed.

Rafaeli and Noy (2002) provide an example of compositional style in which they adopt a theoretical premise and design an interactive experiment to test three theory-derived propositions. Sixty-five MBA students participated in a series of online auctions and interacted in four scenarios with different manipulation conditions. The authors collected experimental data from the simulation tools and questionnaires. The paper's contribution style involves theoretical development in the form of statistically tested hypotheses that confirm the existence of social facilitation effects in online bidding behavior.

Papers in the elementary cluster mainly focus on trade-offs and optimization problems. Consistent with the syntax view of information, which characterizes the vast majority of these papers (84\%), these papers 
assume that systems can achieve a state of (dynamic) equilibrium with their environment. The premise style is mostly based on practical problems related to different areas of concern such as software development (Chiang \& Mookerjee, 2004; Port \& Bui, 2009), IT service pricing (Das, Du, Gopal, \& Ramesh, 2010; Sen, Raghu, \& Vinze, 2009), risk management (Hu, Shao, Hua, \& Wong, 2012; Hua \& Bapna, 2013; Kumar, Park, \& Subramaniam, 2008), and dynamic resource allocation (Ba, Stallaert, \& Zhang, 2010; Velu, Madnick, \& Van Alstyne, 2013). The inference style is mostly based on the literature concerning equilibrium models (e.g., game theory, differential equations, etc.) whose parameters are calibrated with data from previous studies, real-life cases, or realistic examples. The contribution styles span from artifacts' embedding the simulation model (e.g., Choi et al., 2010) to theoretical developments in which hypotheses are formulated and tested with simulation.

Choi et al. (2010) provide an example of compositional style in which they adopt a practical premise and develop and validate a system dynamic model (deductive style) in order to contribute with a decision support system that embeds the model. They address the problem of assessing the pros and cons of early versus late adoption of service oriented architecture (SOA). They use a system dynamics approach to evaluate the efficacy of SOA under diverse environmental and industry conditions. They present the advantages of building a system dynamics representation (e.g., possibility to represent both quantifiable and hard-tomeasure variables, etc.) and describe the main constructs of this simulation approach (e.g., stocks, flows, converters, connectors, feedback processes, etc.). They depict a causal loop model of SOA adoption with positive and negative relationships between constructs. They calibrate the model using findings from the literature and include detailed specifications of all model constructs in the paper's appendix, which shows the mathematical relationships, constants employed, and the initial values of accumulating constructs. They validate the model via both structural and behavioral pattern testing. Finally, they present the results of systematically exploring the problem space (pragmatic experimentation) by evaluating the model for several different organizational and industry conditions and scenarios.

Papers in the situated cluster mostly focus on the emergence of collective effects from some micro-level mechanism. Team and process performance (Curşeu, 2006; Raghu, Jayaraman, \& Rao, 2004b; Rao et al., 1995), collective IT use and adoption (Nan \& Johnston, 2009; Nan, 2011; Walden \& Browne, 2009), and competitive advantage (Chang, Oh, Pinsonneault, \& Kwon, 2010; Clemons, Gu, \& Lang, 2002) are examples of collective effects determined by structural and behavioral characteristics of the underlying socio-technical processes. The premise style is often theoretical, and authors draw on previous works to construct theoretical propositions that they illustrate in a specific domain. The inference style is predominantly based on domain knowledge with realistic examples for calibrating the model. Rather than testing hypotheses, the contribution style focuses mostly on gaining qualitative insights into theoretical proposition.

Chang et al. (2010) provide an example of such composition style by investigating the effects of influence network, individual preferences and global cascading on strategic alliances in the context of online advertising. They use mathematical notation to represent the factors that affect an agent's choices and the probability the agent will move into a different state at time $t+1$. They operationalize the micro-level mechanisms and the captured output into an agent-based model whose simulation pseudocode they describe in the paper's appendix. They use different approaches to calibrate the model in order to ensure the consistency and reliability of their simulations. Specifically, they estimate parameters referring to previous studies, by running pre-simulation experiments, by conducting rounds of "what-if" analyses for assessing contingencies, and by reporting the average values of multiple simulation runs in all the results. The contribution style is based on exploring different experimental scenarios guided by the theoretical propositions. Table 2 summarizes the IS phenomena and the main key findings for each cluster.

From analyzing and interpreting compositional styles in IS simulation studies, we derive a set of stylized facts in the form of simulation studies' possible premises, inferences, and contributions (see Table 3). Simulation studies can adopt either a practical or theoretical premise style whose arguments primarily rest on challenges of IS practice or IS theory, respectively. Also, the inference style varies from studies that ground the simulation model on previous studies and that ground it on evidence from the field. Finally, regarding contribution, the studies complement their theoretical development by designing and evaluating artifacts that embed the simulation models and by exploring and analyzing alternative scenarios. We refer to the latter style of contribution as pragmatic experimentation in order to stress the what-might-be orientation (Burton \& Obel, 2011) of some simulation studies that assume a pragmatic view of knowledge (Romme, 2003).

Table 2. Clusters Summary

\begin{tabular}{l|l} 
Cluster & IS phenomena
\end{tabular} Key findings 
Table 2. Clusters Summary

\begin{tabular}{|c|c|c|}
\hline \multirow{3}{*}{$\begin{array}{l}\text { Self- } \\
\text { organizing }\end{array}$} & $\begin{array}{l}\text { Human computer } \\
\text { interaction }\end{array}$ & $\begin{array}{l}\text { - Effects of visualization techniques on knowledge discovery (Chung et al., } \\
\text { 2005) }\end{array}$ \\
\hline & $\begin{array}{l}\text { Knowledge } \\
\text { coordination }\end{array}$ & $\begin{array}{l}\text { - Evolution and impact of transaction memory systems on virtual team } \\
\text { performances (Kanawattanachai \& Yoo, 2009) }\end{array}$ \\
\hline & $\begin{array}{l}\text { Online } \\
\text { marketplaces }\end{array}$ & $\begin{array}{l}\text { - Effects of information revelation policies on the bidding behavior of } \\
\text { suppliers in reverse e-marketplace (Greenwald et al., 2009) } \\
\text { - Effects of bidding strategies on online auctions (Bapna et al., 2003) } \\
\text { - Effects of social facilitation in online bidding behavior (Rafaely \& Noy, 2002) }\end{array}$ \\
\hline \multirow{3}{*}{ Elementary } & IT governance & $\begin{array}{l}\text { - Strategies for system integration (Chiang \& Mookerjee, 2004) and } \\
\text { requirement prioritization (Port \& Bui, 2009) in software development }\end{array}$ \\
\hline & IT services & - Dynamic pricing for online IT services (Das et al., 2010, Kumar et al., 2008) \\
\hline & $\begin{array}{l}\text { IT infrastructure } \\
\text { design }\end{array}$ & $\begin{array}{l}\text { - Assessment of pros and cons of service-oriented architecture adoption (Choi } \\
\text { et al., 2010) } \\
\text { - Trade-offs in balancing e-services and human services (Ba et al. 2010) and } \\
\text { centralizing data management (Velu et al. 2013) }\end{array}$ \\
\hline \multirow{3}{*}{ Situated } & $\begin{array}{l}\text { Team and process } \\
\text { performance }\end{array}$ & $\begin{array}{l}\text { - Effects of group support systems on virtual teams (Curseu, 2006) } \\
\text { - Effects of incentives (schemes and information access) on salesforce (Raghu } \\
\text { et al., 2004) and team (Rao et al., 1995) performance }\end{array}$ \\
\hline & $\begin{array}{l}\text { Collective IT use } \\
\text { and adoption }\end{array}$ & $\begin{array}{l}\text { - Effects of facilitation practices on the use of Group Support Systems (Nan \& } \\
\text { Johnston, 2009) } \\
\text { - Effects of learning rates, IT tool (incident tracking support system) flexibility, } \\
\text { and workplace rigidity on IT-based work performance (Nan, 2011) } \\
\text { - Effects of group and individual sequential adoption of IT on the convergence } \\
\text { of adoption decisions (Walden \& Browne, 2009) }\end{array}$ \\
\hline & $\begin{array}{l}\text { Competition in } \\
\text { online markets }\end{array}$ & $\begin{array}{l}\text { - Thresholds of market shares for strategic alliances in online advertising } \\
\text { (Chang et al., 2010) } \\
\text { - Prediction on the profitability of business models in the music industry and } \\
\text { newspapers (Clemons et al., 2002) }\end{array}$ \\
\hline
\end{tabular}

Table 3. Structural Patterns in Simulation Studies

\begin{tabular}{|l|l|l|}
\hline \multicolumn{1}{|c|}{ Premise style } & \multicolumn{1}{|c|}{ Inference style } & \multicolumn{1}{c|}{ Contribution style } \\
\hline $\begin{array}{l}\text { Practical: argument primarily based } \\
\text { on challenges in IS practice }\end{array}$ & $\begin{array}{l}\text { Field based: simulation model } \\
\text { primarily grounded in evidence from } \\
\text { the field }\end{array}$ & $\begin{array}{l}\text { Theoretical development: tested } \\
\text { hypotheses and propositions }\end{array}$ \\
\hline $\begin{array}{l}\text { Theoretical: argument primarily } \\
\text { based in challenges in IS theory }\end{array}$ & $\begin{array}{l}\text { Literature based: simulation model } \\
\text { primarily grounded in concepts from } \\
\text { the literature and then calibrated and } \\
\text { validated through empirical data }\end{array}$ & $\begin{array}{l}\text { Artifact design: design and } \\
\text { evaluation of an artifact that embeds } \\
\text { the simulation model }\end{array}$ \\
\hline & & $\begin{array}{l}\text { Pragmatic experimentation: } \\
\text { exploration of alternative scenarios }\end{array}$ \\
\hline
\end{tabular}

We can derive additional stylized facts by focusing on patterns among clusters of simulation papers and their compositional styles. We group papers that focus on adaptive behaviors, trade-offs and optimization, and emergence of collective effects into clusters named self-organizing, elementary, and situated, respectively. However, coherent with the conceptualization of stylized facts that Houy, Fettke, Loos, Houy, and Loos (2015) provide, clusters do not provide a sharp distinction with respect to compositional styles, and one can find similar instances in different clusters. For instance, Dutta's (2001) study on the effects of price for network services on growth strategies from the self-organizing cluster adopts the same compositional style of the above-mentioned work on SOA (Choi et al., 2010) from the elementary cluster. Nevertheless, we find it useful to refer to the three clusters in order to identify examples of simulation studies that present the results of experiments, system dynamics, and agent-based models. Table 4 provides examples of configurations found in the literature. 
Table 4. Examples of Configurations

\begin{tabular}{|c|c|c|c|c|}
\hline Study & Cluster & $\begin{array}{c}\text { Premise } \\
\text { style }\end{array}$ & Inference style & Contribution style \\
\hline Rafaeli \& Noy (2002) & Self-organizing & Theoretical & Field & Theoretical development \\
\hline Abdel-Hamid ( 1988) & Self-organizing & Practical & Field & Pragmatic experimentation \\
\hline Choi et al. (2010) & Elementary & Practical & Literature & $\begin{array}{c}\text { Artifact design } \\
\text { Pragmatic experimentation }\end{array}$ \\
\hline Port \& Bui (2009) & Elementary & Theoretical & Literature & Theoretical development \\
\hline Chang et al. (2010) & Situated & Practical & Field & Pragmatic experimentation \\
\hline Nan \& Johnston (2009) & Situated & Theoretical & Literature & Theoretical development \\
\hline
\end{tabular}

From analyzing stylized facts, we discovered interesting insights on the ways in which simulation studies contribute to knowledge development in the IS field. First, the fact that the literature uses different compositional styles independently from both simulation types and clusters denotes that simulation research practitioners experience some difficulty in presenting their findings in ways that the general research community can recognize. Furthermore, the multiplicity of contributions that a single study provides suggests we need to reflect more on the value construction in simulation research (Zhang \& Gable, 2014). In fact, though published in top-tier IS journals, researchers often perceive simulation studies as having a low level of impact. By analyzing a similar sample of papers, Zhang and Gable (2014) have recently proposed a typology of simulation contributions. Our results contribute to this debate by informing reviewers and future researchers about structural patterns to design and present simulation studies.

In addition, our analysis suggests that we need to emphasize not only the ways in which we can use simulation techniques in IS studies but also the ontological and epistemological assumptions that we make in modeling reality. Our reflection on stylized facts related to clusters configurations can support researchers in identifying a proper strategy to conduct a simulation study. Further, we found that researchers have often adapted pragmatic experimentation as a complementary contribution style together with theoretical development and artifact design, which seems to confirm the advantages of simulation research in investigating what-might-be problems and triangulating results with other research methods (Burton \& Obel, 2011). As such, simulation modeling may be effectively employed at the interface between the descriptive and the design modes of research. In line with Romme's (2003) definition, simulation modeling allows people to build and test models that describe the current and desired (states of) a system, which helps them to move outside the mental boundaries of the current situation. Therefore, simulation research practitioners may want to emphasize the constructive nature of the knowledge generated via simulations, going beyond traditional descriptive knowledge (based on explanation and understanding) while generating prescriptive, normative, and prospective knowledge under the paradigm of pragmatism (Goldkuhl, 2012).

\section{Discussion and General Implications}

In this review, we not only descriptively analyze simulation studies in IS research and derive structural dimensions and related categories but also use these dimensions and categories to qualitatively and quantitatively analyze the dataset. As a result, we propose stylized facts through which prospective authors of simulation studies may develop, emphasize, and present elements of their research more systematically.

This insight could be useful as a methodological support in the context of IS, the domain for which our research focuses on providing foundational knowledge. If one seeks to move beyond describing a sociotechnical process, one can viably develop a simulation model to conduct one's study. Depending on the ontological and epistemological assumptions made in representing the reality, one can use different simulation techniques to fulfill one's research goals. The decision model that Figure 8 represents summarizes possible choices that the IS researcher can make in designing a simulation study. The schema draws on our findings and provides actionable support in defining a suitable simulation approach.

The first decision concerns time. If the phenomenon under investigation evolves over time, static simulation models such as Monte Carlo cannot represent the system (Law \& Kelton, 2003). Conversely, if one seeks to investigate a system's dynamics, one must adopt either a global perspective or a focus on local interactions among systems components. In the former case, the model offers a macro-level representation of the whole system that can be expressed either in closed form as a mathematical function (AN) or as a causal loop and chain of events (SD) (Dutta \& Roy, 2005; Gilbert \& Troitzsch, 2005). In the latter case, if one focuses on local interactions, one must make assumptions on the nature of information. According with Mckinney and 
Yoos (2010), one adopts an objective interpretation when structure and meaning emerge from a sign that stands for an object to a particular observer. Instead, subjective interpretations also assume the emergence of a historic background. These assumptions are crucial for modeling IS interactions, and, according to our results, they determine whether the final model will belong to the "self-organizing" or in the "situated" cluster. In the first case, one must make a decision on the role of IT in experimental design. One can mix or complement traditional laboratory experiments, in which IT tools and platforms support human interactions, with virtual experiments in which agents learn from past interactions (Nan, 2011; Reed, 1997). In the second case, one must make a choice on the level of sophistication of the agents and their environment. The final model may include agents' performing simple tasks (e.g., NK fitness landscape model) and focus on optimization problems (Dawande et al., 2008). An alternative can be a set of agents who can manage different levels of memory, have sophisticated cognitive aspects (e.g., specific rules of engagement), and can interact (potentially) with all the agents (not only locally) in the environment (Adomavicius, Gupta, \& Zhdanov, 2009; Chaturvedi, Dolk, \& Drnevich, 2011; Gilbert \& Troitzsch, 2005).

Our findings show that agent-based simulation is the more flexible and versatile technique. In fact, AG papers are the only ones applied to all research domains (individual behavior, organizational behavior, and IT artifact). We can make an interesting distinction between models based on a small number of agents with sophisticated abilities and that can potentially interact with any other agent (Druckenmiller \& Acar, 2009; Guo, Koehler, \& Whinston, 2012) with models that deal with a large population of simple agents who interact at a local level (Verel et al., 2007). Additional applications of AG simulations are controlled experiments in which IT tools interact with human actors and/or with software agents with predictive capabilities based on machine learning implementations.

Although previous work sharply distinguishes between virtual experiments (Burton \& Obel, 2011; Davis, Eisenhardt, \& Bingham, 2007; Harrison et al., 2007) and traditional laboratory experiments, our results show that one can model IS phenomena by mixing computational and human components. By espousing the broad definition of simulation as a means to reproduce the system behavior in a controlled environment, we encourage researchers to design experiments in which the computational component can play different roles-from support tool for human interactions in a controlled environment to artificial agents performing actions. Our results show that a decision model for the design of simulation studies in the IS field can include human-based simulation as a possible option for developing theories with mixed methods under the whatmight-be research paradigm.

Nevertheless, for our purposes here, we included in our dataset only papers that explicitly mention the word "simulation" either in the title, abstract, or keywords. Though our study includes works related to simulation games, our study does not comprehensive review experimental research in the IS field. As such, future research could further investigate the role of IT artifacts in experimental research and, hence, the relation between virtual and traditional experiments that are seldom considered as two sides of the same coin. 


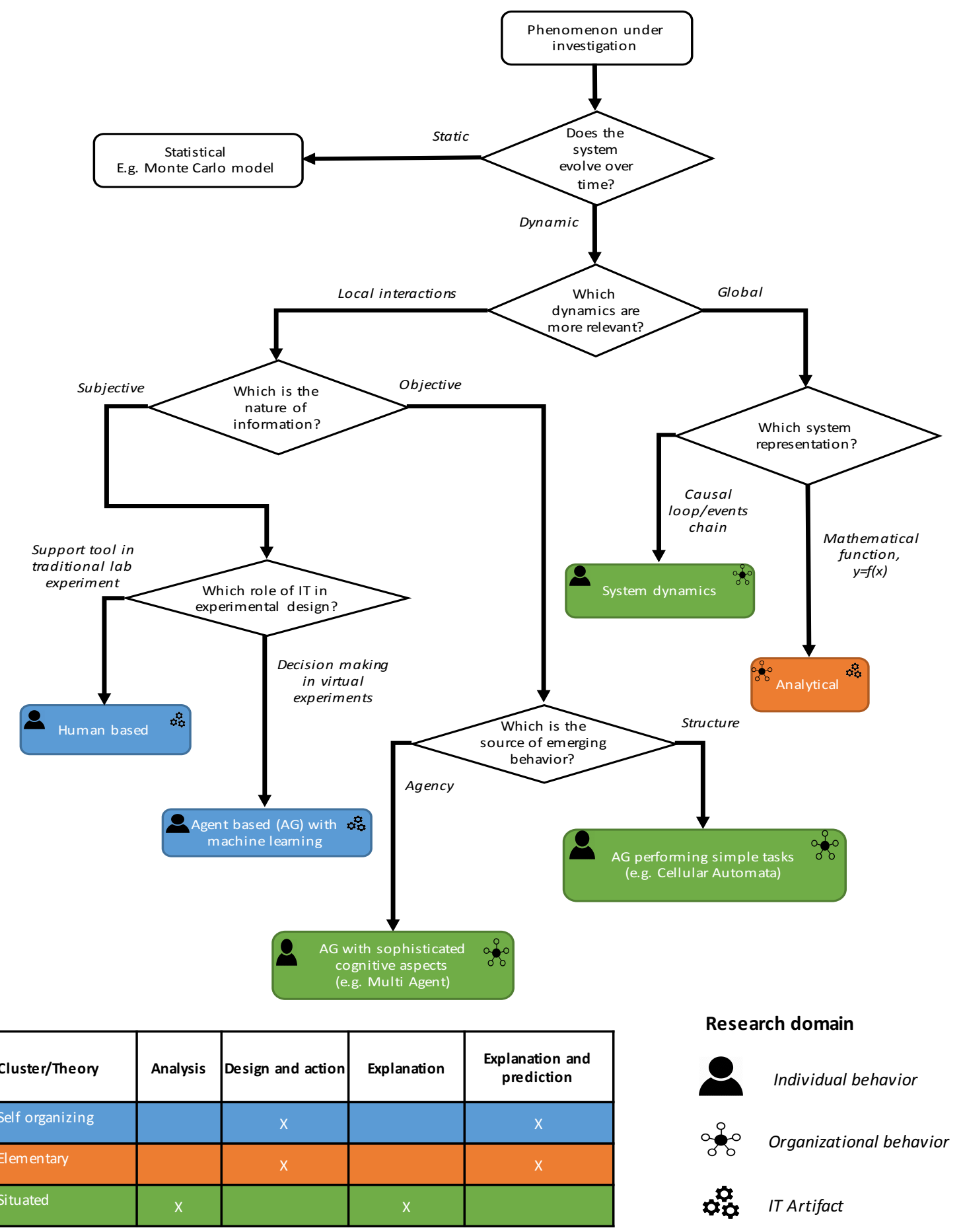

Figure 8. Decision Model for Simulation Studies in IS Research

Once researchers have positioned themselves in the self-organizing, elementary, or situated cluster, they can expect that analyzing the respective cluster in detail will provide more detailed insights into the role of empirical data and on the appropriate styles for presenting a paper's premises and the contribution. Such methodological recommendations can support the research design effort by pointing to examples of successful configurations of research goals, simulation techniques, and presentation patterns.

In addition to the guidance that our review of simulation studies in the IS field provides, researchers can find inspiration from successful applications of simulations in other fields, such as management, physics, and economics. Some of the most influential works in management sciences use computational modeling and simulations (e.g., March, 1991; Levinthal, 1997). These works continue to provide a foundation for 
studies on organizational topics such as social learning (Lazer \& Friedman, 2007) and system integration (Brusoni, Marengo, Prencipe, \& Valente, 2007). Nevertheless, today's availability of a large amount of data together with new developments in network theories and the diffusion of predictive tools based on real-time analytics (e.g., Tria, Loreto, Servedio, \& Strogartz, 2014) extend our abilities to simulate the behavior of complex socio-technical systems (Vespignani, 2009). IS scholars should not overlook this opportunity and reflect on possible ways to develop knowledge in relevant domains such as energy distribution, urban planning, epidemiology, finance, human resources, and crisis management.

\section{Conclusions}

By exploring the foundations of previous studies that have adopted simulation in IS research, we provide actionable guidance to future simulation researchers in the form of a decision model and key references on stylized facts. In translating the uses of simulation by existing high-quality research papers into methodological recommendations in such a straightforward way, we might have "overlooked" some applications. There might always exist new and promising ways to approach a research question beyond what guidelines that rely on empirical evidence suggest. Patterns help to find a promising starting point and to avoid clear dead ends. Patterns should, however, not replace methodological creativity, especially in a research field (compared to reference fields) whose comparatively lower maturity always suggests that one be open to approaches that go beyond established patterns.

Our research also paves the road to further studies that can either apply a similar approach to investigate other research practices or can propose innovative ways to deploy simulations. In the former case, future research can translate our multi-lens conceptualization for analyzing research goals, assumptions, and presentation patterns with a mixed-methods approach to explore other practices such as evaluation, experiments, or case studies. In the latter, the future research can use the conceptual structure of simulation applications to identify new ways to deploy simulation. For instance, one could employ large-scale humanbased experiments and sophisticated models of agent interactions to study the effects of tasks, information, and knowledge structures on the dynamics of groups and online communities.

As the descriptive analysis of our dataset shows, Decision Support Systems has published the most significant number of simulation studies. Though not included in the "basket of eight", DSS has an impact factor in line with other top-tier IS journals and shows a strong design orientation. In fact, it covers both theoretical and technical issues in the support of enhanced decision making, and research in the journal has often evaluated foundations, functionalities, and interfaces of DSS through simulations. Although we agree that DSS does represent a key reference point for scholars who engage with simulation studies in IS, we restricted the analysis only to basket journals based on the need to give guidance and orientation to IS scholars in more general terms. In this way, we explore a variety of goals and means to use simulation for theory building in the IS field. Future studies can apply our categories and results (e.g., stylized facts) to analyzing different datasets including papers published by specialized journals such as DSS or the Journal of Simulation.

Since we focus on IS research in this study, our analysis does not cover more "technical" research papers (e.g., those published in ACM transactions or IEEE transactions journals). The same limitation holds for recent studies and for research results that have been published in outlets beyond our scope of analysis (e.g., conference proceedings). Like in any explorative study, analysis results might differ if one includes or excludes additional observations. We are, however, confident that the current selection of outlets is sufficiently representative to explore useful hypotheses for further research. 


\section{References}

Abdel-Hamid, T. (1988). The economics of software quality assurance: A simulation-based case study. MIS Quarterly, 12(3), 395-411.

Adomavicius, G., Gupta, A., \& Zhdanov, D. (2008). Designing intelligent software agents for auctions with limited information feedback. Information Systems Research, 20(4), 507-526.

Allen, P. M., \& Varga, L. (2006). A co-evolutionary complex systems perspective on information systems. Journal of Information Technology, 21(4), 229-238.

Ba, S., Stallaert, J., \& Zhang, Z. (2010). Balancing IT with the human touch: Optimal Investment in IT-based customer service. Information Systems Research, 21(3), 423-442.

Balijepally, V., Mangalaraj, G., \& Iyengar, K. (2011). Are we wielding this hammer correctly? A reflective review of the application of cluster analysis in Information Systems Research. Journal of the Association for Information Systems, 12(5), 375-413.

Bapna, R., Goes, P., \& Gupta, A. (2003). Replicating online Yankee auctions to analyze auctioneers' and bidders' strategies. Information Systems Research, 14(3), 244-268.

Barbati, M., Bruno, G., \& Genovese, A. (2012). Applications of agent-based models for optimization problems: A literature review. Expert Systems with Applications, 39(5), 6020-6028.

Beese, J., Haki, K., \& Aier, S. (2015). On the conceptualization of information systems as socio-technical phenomena in simulation-based research. In Proceedings of 36th International Conference on Information Systems.

Brusoni, S., Marengo, L., Prencipe, A., \& Valente, M. (2007). The value and costs of modularity: A problemsolving perspective. European Management Review, 4(2), 121-132.

Burton, R., \& Obel, B. (2011). Computational modeling for what-is, what-might-be, and what-should-be studies-and triangulation. Organization Science, 22(5), 1195-1202.

Carley, K. M. (2001). Computational approaches to sociological theorizing. In J. Turner (Ed.), Handbook of sociological theory (pp. 69-84). New York: Kluwer Academic/Plenum.

Casti, J. L. (1997). Would-be worlds: How simulation is changing the frontiers of science. New York, NY: John Wiley and Sons.

Chang, R. M., Oh, W., Pinsonneault, A., \& Kwon, D. (2010). A network perspective of digital competition in online advertising industries: A simulation-based approach. Information Systems Research, 21(3), 571-593.

Chaturvedi, A., Dolk, D., \& Drnevich, P. (2011). Design principles for virtual worlds. MIS Quarterly, 35(3), 673-684.

Chiang, I. R., \& Mookerjee, V. S. (2004). A fault threshold policy to manage software development projects. Information Systems Research, 15(1), 3-21.

Choi, J., Nazareth, D. L., \& Jain, H. K. (2010). Implementing service-oriented architecture in organizations. Journal of Management Information Systems, 26(4), 253-286.

Chung, W., Chen, H., \& Nunamaker, J. F. (2005). A visual framework for knowledge discovery on the Web: An empirical study of business intelligence exploration. Journal of Management Information Systems, 21(4), 57-84.

Clemons, E., Gu, B., \& Lang, K. (2002). Newly vulnerable markets in an age of pure information products: An analysis of online music and online news. Journal of Management Information Systems, 19(3), 17-41.

Culnan, M. J. (1986). The intellectual development of management information systems, 1972-1982: A cocitation analysis. Management Science, 32(2), 156-172.

Curşeu, P. L. (2006). Emergent states in virtual teams: A complex adaptive systems perspective. Journal of Information Technology, 21(4), 249-261.

Das, S., Du, A. Y., Gopal, R., \& Ramesh, R. (2010). Risk management and optimal pricing in online storage grids. Information Systems Research, 22(4), 756-773. 
Datta, A., Dutta, K., Liang, Q., \& VanderMeer, D. (2012). SOA performance enhancement through XML fragment caching. Information Systems Research, 23(2), 505-535.

Davis, J. P., Eisenhardt, K. M., \& Bingham, C. B. (2007). Developing theory through simulation methods. Academy of Management Review, 32(2), 480-499.

Dawande, M., Johar, M., Kumar, S., \& Mookerjee, V. S. (2008). A comparison of pair versus solo programming under different objectives: An analytical approach. Information Systems Research, 19(1), 71-92.

Delanda, M. (2011). Philosophy and simulation: The emergence of synthetic reason. London, New York: Continuum International Publishing Group.

Druckenmiller, D. A., \& Acar, W. (2009). An agent-based collaborative approach to graphing causal maps for situation formulation. Journal of the Association for Information Systems, 1O(3), 221-251.

Dutta, A. (2001). Business planning for network services: A systems thinking approach. Information Systems Research, 12(3), 260-283.

Dutta, A., \& Roy, R. (2005). Offshore outsourcing: A dynamic causal model of counteracting forces. Journal of Management Information Systems, 22(2), 15-35.

Fazlollahi, B., \& Vahidov, R. (2001). A method for generation of alternatives by decision support systems. Journal of Management Information Systems, 18(2), 229-250.

Gilbert, N., \& Troitzsch, K. G. (2005). Simulation for the social scientist. Open University Press.

Goldkuhl, G. (2012). Pragmatism vs interpretivism in qualitative information systems research. European Journal of Information Systems, 21(2), 135-146.

Greenwald, A., Kannan, K., \& Krishnan, R. (2009). On evaluating information revelation policies in procurement auctions: A Markov decision process Approach. Information Systems Research, 21(1), 15-36.

Gregor, S. (2006). The nature of theory in information systems. MIS Quarterly, 30(3), 611-642.

Gregor, S., \& Hevner, A. R. (2013). Positioning and presenting design science research for maximum impact. MIS Quarterly, 37(2), 337-355.

Gregor, S., \& Jones, D. (2007). The anatomy of a design theory. Journal of the Association for Information Systems, 8(5), 312-335.

Grover, V., Ayyagari, R., Gokhale, R., \& Lim, J. (2006). A citation analysis of the evolution and state of information systems within a constellation of reference disciplines. Journal of the Association for Information Systems, 7(5), 270-325.

Guo, Z., Koehler, G., \& Whinston, A. (2012). A computational analysis of bundle trading markets design for distributed resource allocation. Information Systems Research, 23(3-NaN-1), 823-843.

Harrison, J., Zhiang, R., Carrol, G., \& Carley, K. M. (2007). Simulation modeling in organizational and management research. Academy of Management Review, 32(4), 1129-1245.

Hevner, A. R., March, S. T., Park, J., \& Ram, S. (2004). Design science in information systems research. MIS Quarterly, 28(1), 75-105.

Houy, C., Fettke, P., Loos, P., Houy, C., \& Loos, P. (2015). Stylized facts as an instrument for literature review and cumulative information systems research. Communications of the AIS, 37, 225-256.

Hu, D., Shao, J., Hua, Z., \& Wong, M. C. S. (2012). Network-based modeling and analysis of systemic risk in banking systems. MIS Quarterly, 36(4), 1269-1291.

Hua, J., \& Bapna, S. (2013). The economic impact of cyber terrorism. Journal of Strategic Information Systems, 22(2), 175-186.

Kanawattanachai, P., \& Yoo, Y. (2002). Dynamic nature of trust in virtual teams. Journal of Strategic Information Systems, 11(3-4), 187-213.

Kanawattanachai, P., \& Yoo, Y. (2007). The impact of knowledge coordination on virtual team performance over time. MIS Quarterly, 31(4), 783-808. 
Kappos, A., \& Rivard, S. (2008). A three-perspective model of culture, information systems, and their development and use. MIS Quarterly, 32(3), 601-634.

Keen, R. E., \& Spain, J. D. (1994). Computer simulation in biology: A basic introduction (2nd ed.). New York, NY, USA: John Wiley \& Sons.

Ketchen, D. J., \& Shook, C. L. (1996). The application of cluster analysis in strategic management research: An analysis and critique. Strategic Management Journal, 17(6), 441-458.

Kolfschoten, G. L., \& de Vreede, G.-J. (2009). A design approach for collaboration processes: A multimethod design science study in collaboration engineering. Journal of Management Information Systems, 26(1), 225-256.

Konana, P., Gupta, A., \& Whinston, A. B. (2000). Integrating user preferences and real-time workload in information services. Information Systems Research, 11(2), 177-196.

Kulik, B. W., \& Baker, T. (2008). Putting the organization back into computational organization theory: A complex Perrowian model of organizational action. Computational and Mathematical Organization Theory, 14(2), 84-119.

Kumar, R. L., Park, S., \& Subramaniam, C. (2008). Understanding the value of countermeasure portfolios in information systems security. Journal of Management Information Systems, 25(2), 241-280.

Law, A. M., \& Kelton, D. W. (1991). Simulation modeling and analysis (2nd ed.). New York: McGraw-Hill.

Lazer, D., \& Friedman, A. (2007). The network structure of exploration and exploitation. Administrative Science Quarterly, 52(1995), 667-694.

Lee, A. S. (2010). Retrospect and prospect: Information systems research in the last and next 25 years. Journal of Information Technology, 25(4), 336-348.

Lee, A. S., \& Baskerville, R. L. (2003). Generalizing generalizability in information systems research. Information Systems Research, 14(3), 221-243.

Lee, J. H., \& Kim, C. O. (2008). Multi-agent systems applications in manufacturing systems and supply chain management: A review paper. International Journal of Production Research, 46(1), 233-265.

Leonardi, P. (2013). Theoretical foundations for the study of sociomateriality. Information and Organization, 23(2), 59-76.

Levinthal, D.A. (1997). Adaptation on rugged landscapes. Management Science, 43(7), 934-950.

Lowry, P. B., Moody, G. D., Gaskin, J., Galletta, D. F., Humpherys, S. L., Barlow, J. B., \& Wilson, D. W. (2013). Evaluating journal quality and the Association for Information Systems Senior Scholars' journal basket via bibliometric measures: Do expert journal assessments add value? MIS Quarterly, 37(4), 993-1012.

MacQueen, J. (1965). Some methods for classification and analysis of multivariate observations. In Proceedings of the 5th Berkeley Symposium on Mathematical Statistics and Probability.

March, J. G. (1991). Exploration and exploitation in organizational learning. Organization Science, 2(1), 7187.

March, S. T., \& Smith, G. F. (1995). Design and natural science research on information technology. Decision Support Systems, 15(4), 251-266.

Mathiassen, L., Chiasson, M., \& Germonprez, M. (2012). Style composition in action research publication. MIS Quarterly, 36(2), 347-363.

Mayring, P. (2003). Qualitative Inhaltanalyse - Grundlagen und Techniken (8th ed.). Weinheim: Beltz Verlag.

Mckinney, E. J., \& Yoos, C. I. (2010). Information about information: A taxonomy of views. MIS Quarterly, 34(2), 329-344.

Mettler, T., Eurich, M., \& Winter, R. (2014). On the use of experiments in design science research: A Proposition of an evaluation framework. Communications of the AIS, 34(12), 223-240.

Mielczarek, B., \& Uzialko-Mydlikowska, J. (2010). Application of computer simulation modeling in the health care sector: A survey. Simulation, 88(2), 197-216. 
Mitra, S., Sambamurthy, V., \& Westerman, G. (2011). Measuring IT performance and communicating value. MIS Quarterly Executive, 10(1), 47-59.

Mookerjee, V. S., Mannino, M. V., \& Gilson, R. (1995). Improving the performance stability of inductive expert systems under input noise. Information Systems Research, 6(4), 328-356.

Myers, M. D. (1999). Investigating information systems with ethnographic research. Communications of the AIS, 2, 2-19.

Nan, N. (2011). Capturing bottom-up information technology use processes: A complex adaptive systems model. MIS Quarterly, 35(2), 505-532.

Nan, N., \& Johnston, E. (2009). Using multi-agent simulation to explore the contribution of facilitation to GSS transition. Journal of the Association for Information Systems, 10(3), 252-277.

Nguyen, T. N. (2005). The software continuum concept: towards a biologically inspired model for robust ebusiness software automation. Communications of the Association for Information Systems, 15, 263288.

Nickerson, R. C., \& Varshney, \& Muntermann, J. (2013). A method for taxonomy development and its application in information systems. European Journal of Information Systems, 22, 336-359.

Niederman, F., Davis, A., Greiner, M., Wynn, D., \& York, P. (2006). A research agenda for studying open source I: A multi-level framework. Communications of the AIS, 18, 129-149.

Oh, W., \& Lucas, H. (2006). Information technology and pricing decisions: Price adjustments in online computer markets. MIS Quarterly, 3O(3), 755-775.

Port, D., \& Bui, T. (2009). Simulating mixed agile and plan-based requirements prioritization strategies: Proof-of-concept and practical implications. European Journal of Information Systems, 18(4), 317331.

Punj, G., \& Stewart, D. W. (1983). Cluster analysis in marketing research: Review and suggestions for application. Journal of Marketing Research, 2O(2), 134-148.

Qureshi, I., \& Compeau, D. (2009). Assessing between-group differences in information systems research: A comparison of covariance-and component-based SEM. MIS Quarterly, 33(1), 197-214.

Rafaeli, S., \& Noy, A. (2002). Online auctions, messaging, communication and social facilitation: A simulation and experimental evidence. European Journal of Information Systems, 11(3), 196-207.

Raghu, T. S., Jayaraman, B., \& Rao, H. R. (2004a). Toward an integration of agent- and activity-centric approaches in organizational process modeling: Incorporating incentive mechanisms. Information Systems Research, 15(4), 316-335.

Raghu, T. S., Jayaraman, B., \& Rao, H. R. (2004b). Toward an integration of agent- and activity-centric approaches in organizational process modeling: Incorporating incentive mechanisms. Information Systems Research, 15(4), 316-335.

Rao, H., Chaudhury, A., \& Chakka, M. (1995). Modeling team processes: Issues and a specific example. Information Systems Research, 3(6), 255-285.

Reed, M.I. (1997). In praise of duality and dualism: Rethinking agency and structure in organisational analysis. Organization Studies, 18(1), 21-42.

Romme, A. G. L. (2003). Making a difference: Organization as design. Organization Science, 14(5), 558573 .

Rowe, F. (2014). What literature review is not: Diversity, boundaries and recommendations. European Journal of Information Systems, 23(3), 241-255.

Sen, S., Raghu, T. S., \& Vinze, A. (2009). Demand heterogeneity in IT infrastructure services: Modeling and evaluation of a dynamic approach to defining service levels. Information Systems Research, 2O(2), 258-276.

Seuring, S., \& Muller, M. (2008). From a literature review to a conceptual framework for sustainable supply chain management. Journal of Cleaner Production, 16(5), 1699-1710.

Simon, H. (1996). The sciences of the artificial (3rd ed.). Cambridge, MA: MIT Press. 
Spagnoletti, P., Za, S., \& Winter, R. (2013). Exploring foundations for using simulations in IS research. In Proceedings of the 34th International Conference on Information Systems.

Sterman, J. D. (2001). System dynamics modeling: Tools for learning in a complex world. California Management Review, 43(4), 8-25.

Tria, F., Loreto, V., Servedio, D. P., \& Strogatz, S. H. (2014). The dynamics of correlated novelties. Scientific Reports, 4(5890), 1-8.

Velu, C. K., Madnick, S. E., \& Van Alstyne, M. W. (2013). Centralizing data management with considerations of uncertainty and information-based flexibility. Journal of Management Information Systems, $30(3), 179-212$.

Venkatesh, V., Brown, S. A., \& Bala, H. (2013). Bridging the qualitative-quantitative divide: guidelines for conducting mixed methods research in information systems. MIS Quarterly, 37(1), 21-54.

Verel, S., Collard, P., Tomassini, M., \& Vanneschi, L. (2007). Fitness landscape of the cellular automata majority problem: View from the "Olympus". Theoretical Computer Science, 378(1), 54-77.

Vespignani, A. (2009). Predicting the behavior of techno-social systems. Science, 325(5939), 425-428.

Walden, E., \& Browne, G. (2009). Sequential adoption theory: A theory for understanding herding behavior in early adoption of novel technologies. Journal of the Association for Information Systems, 1O(1), 31-62.

Ward, J. H. (1963). Hierarchical grouping to optimize an objective function. Journal of the American Statistical Association, 58(301), 236-244.

Wastell, D. (1996). Human-machine dynamics in complex information systems: The "microworld" paradigm. Information Systems Journal, 6, 245-260.

Wong, N., Ray, P., Stephens, G., \& Lewis, L. (2012). Artificial immune systems for the detection of credit card fraud: An architecture, prototype and preliminary results. Information Systems Journal, 22(1), 53-76.

Wooldridge, M. (2009). An introduction to multiagent systems (2nd ed.). New York: John Wiley \& Sons.

Yuan, Y., \& McKelvey, B. (2004). Situated learning theory: Adding rate and complexity effects via Kauffman's NK model. Nonlinear Dynamics, Psychology, and Life Sciences, 8(1), 65-101.

Za, S., \& Spagnoletti, P. (2013). Knowledge creation processes in information systems and management: Lessons from simulation studies. In P. Spagnoletti (Ed.), Organization change and information systems (LNISO vol. 2). Heidelberg: Springer.

Zhang, M., \& Gable, G. G. (2014). Rethinking the value of simulation methods in the information systems research field: A call for reconstructing contribution for a broader audience. In Proceedings of the 35th International Conference on Information Systems. 


\section{Appendix A}

Table A1. Simulation-based Research Papers in Top-tier and Second-tier IS Journals

\begin{tabular}{|c|c|}
\hline Journal & Identified papers on simulation \\
\hline Business \& Information Systems Engineering & 7 \\
\hline Decision Support Systems & 238 \\
\hline Electronic Commerce Research And Applications & 24 \\
\hline European Journal of Information Systems* & 5 (5 relevant) \\
\hline Information and Management & 20 \\
\hline Information Systems Frontiers & 39 \\
\hline Information Systems Journal* & 3 (3 relevant) \\
\hline Information Systems Management & 8 \\
\hline Information Systems Research* & 32 (29 relevant) \\
\hline Information Technology Management & 12 \\
\hline International Journal of Electronic Commerce & 11 \\
\hline Journal of Computer Information Systems & 24 \\
\hline Journal of Database Management & 5 \\
\hline Journal of Global Information Management & 1 \\
\hline Journal of Information Technology* & 4 (2 relevant) \\
\hline Journal of Management Information Systems* & 24 (20 relevant) \\
\hline Journal of Organizational Computing And Electronic Commerce & 15 \\
\hline Journal of Strategic Information Systems* & 4(3 relevant) \\
\hline Journal of The Association For Information Systems* & $4(2$ relevant $)$ \\
\hline MIS Quarterly* & $19(12$ relevant $)$ \\
\hline MIS Quarterly Executive & 1 \\
\hline Wirtschaftsinformatik & 5 \\
\hline Total & 505 \\
\hline
\end{tabular}




\section{Appendix B}

Table B1. Restricted dataset in top-tier journals after screening procedure

\begin{tabular}{|c|c|c|c|c|c|c|c|c|c|}
\hline $\begin{array}{c}\text { Cluster } \\
\text { ID }\end{array}$ & $\begin{array}{c}\text { Paper } \\
\text { ID }\end{array}$ & \multicolumn{4}{|c|}{ Paper } & Theory & $\begin{array}{c}\text { Research } \\
\text { domain }\end{array}$ & $\begin{array}{c}\text { Information } \\
\text { view }\end{array}$ & $\begin{array}{c}\text { Simulation } \\
\text { type }\end{array}$ \\
\hline 1 & 1 & Abdel-Hamid, T & $\begin{array}{l}\text { The economics of } \\
\text { software quality } \\
\text { assurance: A } \\
\text { simulation-based } \\
\text { case study }\end{array}$ & MISQ & 1988 & $\begin{array}{l}\text { Explanation } \\
\text { and } \\
\text { prediction }\end{array}$ & IT artifact & Representation & $\begin{array}{l}\text { System } \\
\text { dynamics }\end{array}$ \\
\hline 1 & 2 & Dutta, A & $\begin{array}{l}\text { Business planning } \\
\text { for network } \\
\text { services: A systems } \\
\text { thinking approach. }\end{array}$ & ISR & 2001 & $\begin{array}{l}\text { Explanation } \\
\text { and } \\
\text { prediction }\end{array}$ & $\begin{array}{l}\text { Individual } \\
\text { behavior }\end{array}$ & Representation & $\begin{array}{l}\text { System } \\
\text { dynamics }\end{array}$ \\
\hline 1 & 3 & $\begin{array}{l}\text { Wang, SJ; Wang, } \\
\text { WL; Huang, CT; } \\
\text { Chen, SC }\end{array}$ & $\begin{array}{l}\text { Improving } \\
\text { inventory } \\
\text { effectiveness in } \\
\text { RFID-enabled } \\
\text { global supply chain } \\
\text { with Grey } \\
\text { forecasting model }\end{array}$ & JSIS & 2011 & $\begin{array}{l}\text { Design and } \\
\text { action }\end{array}$ & IT artifact & Representation & $\begin{array}{l}\text { System } \\
\text { dynamics }\end{array}$ \\
\hline 1 & 4 & $\begin{array}{l}\text { Rodrigues, AG; } \\
\text { Williams, TM }\end{array}$ & $\begin{array}{l}\text { System dynamics in } \\
\text { software project } \\
\text { management: } \\
\text { Towards the } \\
\text { development of a } \\
\text { formal integrated } \\
\text { framework }\end{array}$ & EJIS & 1997 & $\begin{array}{l}\text { Design and } \\
\text { action }\end{array}$ & IT artifact & Representation & $\begin{array}{l}\text { System } \\
\text { dynamics }\end{array}$ \\
\hline 1 & 5 & $\begin{array}{l}\text { Dawande, Milind; } \\
\text { Johar, Monica; } \\
\text { Kumar, Subodha; } \\
\text { Mookerjee, Vijay } \\
\text { S. }\end{array}$ & $\begin{array}{l}\text { A Comparison of } \\
\text { Pair Versus Solo } \\
\text { Programming } \\
\text { Under Different } \\
\text { Objectives: An } \\
\text { Analytical } \\
\text { Approach } \\
\end{array}$ & ISR & 2008 & $\begin{array}{l}\text { Explanation } \\
\text { and } \\
\text { prediction }\end{array}$ & IT artifact & Representation & Agent based \\
\hline 1 & 6 & $\begin{array}{l}\text { Wong, Nicholas; } \\
\text { Ray, Pradeep; } \\
\text { Stephens, Greg; } \\
\text { Lewis, Lundy }\end{array}$ & $\begin{array}{l}\text { Artificial immune } \\
\text { systems for the } \\
\text { detection of credit } \\
\text { card fraud: an } \\
\text { architecture, } \\
\text { prototype and } \\
\text { preliminary results }\end{array}$ & ISJ & 2012 & $\begin{array}{l}\text { Explanation } \\
\text { and } \\
\text { prediction }\end{array}$ & IT artifact & Representation & Agent based \\
\hline 1 & 7 & $\begin{array}{l}\text { Bapna, R; Goes, } \\
\text { P; Gupta, A }\end{array}$ & $\begin{array}{l}\text { Replicating online } \\
\text { Yankee auctions to } \\
\text { analyze } \\
\text { auctioneers' and } \\
\text { bidders' strategies }\end{array}$ & ISR & 2003 & $\begin{array}{l}\text { Design and } \\
\text { action }\end{array}$ & $\begin{array}{l}\text { Individual } \\
\text { behavior }\end{array}$ & Representation & Agent based \\
\hline 1 & 8 & $\begin{array}{l}\text { Adomavicius, G; } \\
\text { Gupta, A; } \\
\text { Zhdanov, D }\end{array}$ & $\begin{array}{l}\text { Designing } \\
\text { Intelligent Software } \\
\text { Agents for Auctions } \\
\text { with Limited } \\
\text { Information } \\
\text { Feedback }\end{array}$ & ISR & 2009 & $\begin{array}{l}\text { Design and } \\
\text { action }\end{array}$ & $\begin{array}{l}\text { Individual } \\
\text { behavior }\end{array}$ & Representation & Agent based \\
\hline 1 & 9 & $\begin{array}{l}\text { Greenwald, A; } \\
\text { Kannan, K; } \\
\text { Krishnan, R }\end{array}$ & $\begin{array}{l}\text { On Evaluating } \\
\text { Information } \\
\text { Revelation Policies } \\
\text { in Procurement } \\
\text { Auctions: A Markov } \\
\text { Decision Process } \\
\text { Approach }\end{array}$ & ISR & 2010 & $\begin{array}{l}\text { Design and } \\
\text { action }\end{array}$ & $\begin{array}{l}\text { Individual } \\
\text { behavior }\end{array}$ & Representation & Agent based \\
\hline
\end{tabular}


Table B1. Restricted dataset in top-tier journals after screening procedure

\begin{tabular}{|c|c|c|c|c|c|c|c|c|c|}
\hline 1 & 10 & $\begin{array}{l}\text { Webby, R; } \\
\text { Oconnor, M }\end{array}$ & $\begin{array}{l}\text { The Effectiveness } \\
\text { Of Decision- } \\
\text { Support Systems - } \\
\text { The Implications Of } \\
\text { Task Complexity } \\
\text { And Dss } \\
\text { Sophistication }\end{array}$ & JIT & 1994 & $\begin{array}{l}\text { Design and } \\
\text { action }\end{array}$ & $\begin{array}{l}\text { Individual } \\
\text { behavior }\end{array}$ & Adaptation & $\begin{array}{l}\text { Human } \\
\text { based }\end{array}$ \\
\hline 1 & 11 & Wastell, D & $\begin{array}{l}\text { Human-machine } \\
\text { dynamics in } \\
\text { complex } \\
\text { information } \\
\text { systems: The } \\
\text { 'microworld' } \\
\text { paradigm as a } \\
\text { heuristic tool for } \\
\text { developing theory } \\
\text { and exploring } \\
\text { design issues } \\
\end{array}$ & ISJ & 1996 & $\begin{array}{l}\text { Design and } \\
\text { action }\end{array}$ & $\begin{array}{l}\text { Individual } \\
\text { behavior }\end{array}$ & Adaptation & $\begin{array}{l}\text { Human } \\
\text { based }\end{array}$ \\
\hline 1 & 12 & Rafaeli, S; Noy, A & $\begin{array}{l}\text { Online auctions, } \\
\text { messaging, } \\
\text { communication } \\
\text { and social } \\
\text { facilitation: a } \\
\text { simulation and } \\
\text { experimental } \\
\text { evidence }\end{array}$ & EJIS & 2002 & $\begin{array}{l}\text { Design and } \\
\text { action }\end{array}$ & $\begin{array}{l}\text { Individual } \\
\text { behavior }\end{array}$ & Adaptation & $\begin{array}{l}\text { Human } \\
\text { based }\end{array}$ \\
\hline 1 & 13 & $\begin{array}{l}\text { Clemons, EK; } \\
\text { Weber, BW }\end{array}$ & $\begin{array}{l}\text { Alternative } \\
\text { securities trading } \\
\text { systems: Tests and } \\
\text { regulatory } \\
\text { implications of the } \\
\text { adoption of } \\
\text { technology }\end{array}$ & ISR & 1996 & $\begin{array}{l}\text { Explanation } \\
\text { and } \\
\text { prediction }\end{array}$ & $\begin{array}{l}\text { Individual } \\
\text { behavior }\end{array}$ & Adaptation & $\begin{array}{l}\text { Human } \\
\text { based }\end{array}$ \\
\hline 1 & 14 & $\begin{array}{l}\text { Abdel-Hamid, } \\
\text { TK; Sengupta, K; } \\
\text { Swett, C }\end{array}$ & $\begin{array}{l}\text { The impact of goals } \\
\text { on software project } \\
\text { management: An } \\
\text { experimental } \\
\text { investigation }\end{array}$ & MISQ & 1999 & $\begin{array}{l}\text { Explanation } \\
\text { and } \\
\text { prediction }\end{array}$ & $\begin{array}{l}\text { Individual } \\
\text { behavior }\end{array}$ & Adaptation & $\begin{array}{l}\text { Human } \\
\text { based }\end{array}$ \\
\hline 1 & 15 & $\begin{array}{l}\text { Swaab, RI; } \\
\text { Postmes, T; } \\
\text { Neijens, P; Kiers, } \\
\text { MH; Dumay, } \\
\text { ACM }\end{array}$ & $\begin{array}{l}\text { Multiparty } \\
\text { negotiation } \\
\text { support: The role of } \\
\text { visualization's } \\
\text { influence on the } \\
\text { development of } \\
\text { shared mental } \\
\text { models }\end{array}$ & JMIS & 2002 & $\begin{array}{l}\text { Explanation } \\
\text { and } \\
\text { prediction }\end{array}$ & $\begin{array}{l}\text { Individual } \\
\text { behavior }\end{array}$ & Adaptation & $\begin{array}{l}\text { Human } \\
\text { based }\end{array}$ \\
\hline 1 & 16 & $\begin{array}{l}\text { Gupta, S; } \\
\text { Bostrom, R }\end{array}$ & $\begin{array}{l}\text { An Investigation of } \\
\text { the Appropriation } \\
\text { of Technology- } \\
\text { Mediated Training } \\
\text { Methods } \\
\text { Incorporating } \\
\text { Enactive and } \\
\text { Collaborative } \\
\text { Learning }\end{array}$ & ISR & 2013 & $\begin{array}{l}\text { Explanation } \\
\text { and } \\
\text { prediction }\end{array}$ & $\begin{array}{l}\text { Individual } \\
\text { behavior }\end{array}$ & Adaptation & $\begin{array}{l}\text { Human } \\
\text { based }\end{array}$ \\
\hline 1 & 17 & $\begin{array}{l}\text { Chung, W; Chen, } \\
\text { H; Nunamaker, } \\
\text { JF }\end{array}$ & $\begin{array}{l}\text { A visual framework } \\
\text { for knowledge } \\
\text { discovery on the } \\
\text { Web: An empirical } \\
\text { study of business } \\
\text { intelligence } \\
\text { exploration }\end{array}$ & JMIS & 2005 & $\begin{array}{l}\text { Design and } \\
\text { action }\end{array}$ & IT artifact & Adaptation & $\begin{array}{l}\text { Human } \\
\text { based }\end{array}$ \\
\hline
\end{tabular}


Table B1. Restricted dataset in top-tier journals after screening procedure

\begin{tabular}{|c|c|c|c|c|c|c|c|c|c|}
\hline 1 & 18 & $\begin{array}{l}\text { Sniezek, JA; } \\
\text { Wilkins, DC; } \\
\text { Wadlington, PL; } \\
\text { Baumann, MR }\end{array}$ & $\begin{array}{l}\text { Training for crisis } \\
\text { decision-making: } \\
\text { Psychological } \\
\text { issues and } \\
\text { computer-based } \\
\text { solutions }\end{array}$ & JMIS & 2002 & $\begin{array}{l}\text { Design and } \\
\text { action }\end{array}$ & IT artifact & Adaptation & $\begin{array}{l}\text { Human } \\
\text { based }\end{array}$ \\
\hline 1 & 19 & $\begin{array}{l}\text { Fazlollahi, B; } \\
\text { Vahidov, R }\end{array}$ & $\begin{array}{l}\text { A method for } \\
\text { generation of } \\
\text { alternatives by } \\
\text { decision support } \\
\text { systems }\end{array}$ & JMIS & 2001 & $\begin{array}{l}\text { Design and } \\
\text { action }\end{array}$ & IT artifact & Adaptation & $\begin{array}{l}\text { Human } \\
\text { based }\end{array}$ \\
\hline 1 & 20 & $\begin{array}{l}\text { Kanawattanachai, } \\
\text { P; Yoo, Y }\end{array}$ & $\begin{array}{l}\text { Dynamic nature of } \\
\text { trust in virtual } \\
\text { teams }\end{array}$ & JSIS & 2002 & $\begin{array}{l}\text { Explanation } \\
\text { and } \\
\text { prediction }\end{array}$ & $\begin{array}{l}\text { Organizational } \\
\text { behavior }\end{array}$ & Adaptation & $\begin{array}{l}\text { Human } \\
\text { based }\end{array}$ \\
\hline 1 & 21 & $\begin{array}{l}\text { Rafaeli, S; Ravid, } \\
\text { G }\end{array}$ & $\begin{array}{l}\text { Information } \\
\text { sharing as enabler } \\
\text { for the virtual team: } \\
\text { an experimental } \\
\text { approach to } \\
\text { assessing the role of } \\
\text { electronic mail in } \\
\text { disintermediation } \\
\end{array}$ & ISJ & 2003 & $\begin{array}{l}\text { Explanation } \\
\text { and } \\
\text { prediction }\end{array}$ & $\begin{array}{l}\text { Organizational } \\
\text { behavior }\end{array}$ & Adaptation & $\begin{array}{l}\text { Human } \\
\text { based }\end{array}$ \\
\hline 1 & 22 & $\begin{array}{l}\text { Kanawattanachai, } \\
\text { P; Yoo, Y }\end{array}$ & $\begin{array}{l}\text { The impact of } \\
\text { knowledge } \\
\text { coordination on } \\
\text { virtual team } \\
\text { performance over } \\
\text { time }\end{array}$ & MISQ & 2007 & $\begin{array}{l}\text { Explanation } \\
\text { and } \\
\text { prediction }\end{array}$ & $\begin{array}{l}\text { Organizational } \\
\text { behavior }\end{array}$ & Adaptation & $\begin{array}{l}\text { Human } \\
\text { based }\end{array}$ \\
\hline 1 & 23 & $\begin{array}{l}\text { Guo, ZL; Koehler, } \\
\text { GJ; Whinston, } \\
\text { AB }\end{array}$ & $\begin{array}{l}\text { A Computational } \\
\text { Analysis of Bundle } \\
\text { Trading Markets } \\
\text { Design for } \\
\text { Distributed } \\
\text { Resource Allocation }\end{array}$ & ISR & 2012 & $\begin{array}{l}\text { Explanation } \\
\text { and } \\
\text { prediction }\end{array}$ & $\begin{array}{l}\text { Organizational } \\
\text { behavior }\end{array}$ & Adaptation & Agent based \\
\hline 2 & 24 & $\begin{array}{l}\text { Koushik, Mv; } \\
\text { Mookerjee, Vs }\end{array}$ & $\begin{array}{l}\text { Modeling } \\
\text { Coordination In } \\
\text { Software } \\
\text { Construction - An } \\
\text { Analytical } \\
\text { Approach } \\
\end{array}$ & ISR & 1995 & $\begin{array}{l}\text { Explanation } \\
\text { and } \\
\text { prediction }\end{array}$ & $\begin{array}{l}\text { Organizational } \\
\text { behavior }\end{array}$ & Syntax & Analytical \\
\hline 2 & 25 & $\begin{array}{l}\text { Ba, SL; Stallaert, } \\
\text { J; Zhang, ZJ }\end{array}$ & $\begin{array}{l}\text { Balancing IT with } \\
\text { the Human Touch: } \\
\text { Optimal } \\
\text { Investment in IT- } \\
\text { Based Customer } \\
\text { Service }\end{array}$ & ISR & 2010 & $\begin{array}{l}\text { Explanation } \\
\text { and } \\
\text { prediction }\end{array}$ & $\begin{array}{l}\text { Organizational } \\
\text { behavior }\end{array}$ & Syntax & Analytical \\
\hline 2 & 26 & $\begin{array}{l}\text { Hu, DN; Zhao, } \\
\text { JL; Hua, ZM; } \\
\text { Wong, MCS }\end{array}$ & $\begin{array}{l}\text { Network-Based } \\
\text { Modeling And } \\
\text { Analysis Of } \\
\text { Systemic Risk In } \\
\text { Banking Systems }\end{array}$ & MISQ & 2012 & $\begin{array}{l}\text { Explanation } \\
\text { and } \\
\text { prediction }\end{array}$ & $\begin{array}{l}\text { Organizational } \\
\text { behavior }\end{array}$ & Syntax & Analytical \\
\hline 2 & 27 & $\begin{array}{l}\text { Demirkan, H; } \\
\text { Cheng, HK; } \\
\text { Bandyopadhyay, } \\
\text { S } \\
\end{array}$ & $\begin{array}{l}\text { Coordination } \\
\text { Strategies in an } \\
\text { SaaS Supply Chain }\end{array}$ & JMIS & 2010 & $\begin{array}{l}\text { Explanation } \\
\text { and } \\
\text { prediction }\end{array}$ & $\begin{array}{l}\text { Organizational } \\
\text { behavior }\end{array}$ & Syntax & Analytical \\
\hline 2 & 28 & $\begin{array}{l}\text { Bandyopadhyay, } \\
\text { S; } \\
\text { Bandyopadhyay, } \\
\text { S } \\
\end{array}$ & $\begin{array}{l}\text { Estimating Time } \\
\text { Required to Reach } \\
\text { Bid Levels in } \\
\text { Online Auctions }\end{array}$ & JMIS & 2009 & $\begin{array}{l}\text { Explanation } \\
\text { and } \\
\text { prediction }\end{array}$ & $\begin{array}{l}\text { Organizational } \\
\text { behavior }\end{array}$ & Syntax & Analytical \\
\hline 2 & 29 & $\begin{array}{l}\text { Velu, CK; } \\
\text { Madnick, SE; Van } \\
\text { Alstyne, MW }\end{array}$ & $\begin{array}{l}\text { Centralizing Data } \\
\text { Management with } \\
\text { Considerations of } \\
\text { Uncertainty and } \\
\text { Information-Based } \\
\text { Flexibility }\end{array}$ & JMIS & 2013 & $\begin{array}{l}\text { Explanation } \\
\text { and } \\
\text { prediction }\end{array}$ & $\begin{array}{l}\text { Organizational } \\
\text { behavior }\end{array}$ & Syntax & Analytical \\
\hline
\end{tabular}


Table B1. Restricted dataset in top-tier journals after screening procedure

\begin{tabular}{|c|c|c|c|c|c|c|c|c|c|}
\hline 2 & 30 & $\begin{array}{l}\text { Das, S; Du, AY; } \\
\text { Gopal, R; } \\
\text { Ramesh, R }\end{array}$ & $\begin{array}{l}\text { Risk Management } \\
\text { and Optimal } \\
\text { Pricing in Online } \\
\text { Storage Grids }\end{array}$ & ISR & 2011 & $\begin{array}{l}\text { Explanation } \\
\text { and } \\
\text { prediction }\end{array}$ & $\begin{array}{l}\text { Individual } \\
\text { behavior }\end{array}$ & Syntax & Analytical \\
\hline 2 & 31 & Hua, J; Bapna, S & $\begin{array}{l}\text { The economic } \\
\text { impact of cyber } \\
\text { terrorism }\end{array}$ & JSIS & 2013 & $\begin{array}{l}\text { Explanation } \\
\text { and } \\
\text { prediction }\end{array}$ & $\begin{array}{l}\text { Individual } \\
\text { behavior }\end{array}$ & Syntax & Analytical \\
\hline 2 & 32 & $\begin{array}{l}\text { Aloysius, J; Deck, } \\
\text { C; Farmer, A }\end{array}$ & $\begin{array}{l}\text { Sequential Pricing } \\
\text { of Multiple } \\
\text { Products: } \\
\text { Leveraging } \\
\text { Revealed } \\
\text { Preferences of } \\
\text { Retail Customers } \\
\text { Online and with } \\
\text { Auto-ID } \\
\text { Technologies }\end{array}$ & ISR & 2013 & $\begin{array}{l}\text { Explanation } \\
\text { and } \\
\text { prediction }\end{array}$ & $\begin{array}{l}\text { Individual } \\
\text { behavior }\end{array}$ & Syntax & Analytical \\
\hline 2 & 33 & $\begin{array}{l}\text { Bampo, M; } \\
\text { Ewing, MT; } \\
\text { Mather, DR; } \\
\text { Stewart, D; } \\
\text { Wallace, M }\end{array}$ & $\begin{array}{l}\text { The effects of the } \\
\text { social structure of } \\
\text { digital networks on } \\
\text { viral marketing } \\
\text { performance }\end{array}$ & ISR & 2008 & $\begin{array}{l}\text { Explanation } \\
\text { and } \\
\text { prediction }\end{array}$ & $\begin{array}{l}\text { Organizational } \\
\text { behavior }\end{array}$ & Representation & Agent based \\
\hline 2 & 34 & $\begin{array}{l}\text { Choi, J; } \\
\text { Nazareth, DL; } \\
\text { Jain, HK }\end{array}$ & $\begin{array}{l}\text { Implementing } \\
\text { Service-Oriented } \\
\text { Architecture in } \\
\text { Organizations }\end{array}$ & JMIS & 2010 & $\begin{array}{l}\text { Explanation } \\
\text { and } \\
\text { prediction }\end{array}$ & $\begin{array}{l}\text { Organizational } \\
\text { behavior }\end{array}$ & Representation & $\begin{array}{l}\text { System } \\
\text { dynamics }\end{array}$ \\
\hline 2 & 35 & Dutta, A; Roy, R & $\begin{array}{l}\text { Offshore } \\
\text { outsourcing: A } \\
\text { dynamic causal } \\
\text { model of } \\
\text { counteracting } \\
\text { forces }\end{array}$ & JMIS & 2005 & $\begin{array}{l}\text { Explanation } \\
\text { and } \\
\text { prediction }\end{array}$ & $\begin{array}{l}\text { Organizational } \\
\text { behavior }\end{array}$ & Representation & $\begin{array}{l}\text { System } \\
\text { dynamics }\end{array}$ \\
\hline 2 & 36 & $\begin{array}{l}\text { Thatcher, ME; } \\
\text { Clemons, EK }\end{array}$ & $\begin{array}{l}\text { Managing the costs } \\
\text { of informational } \\
\text { privacy: Pure } \\
\text { bundling as a } \\
\text { strategy in the } \\
\text { individual health } \\
\text { insurance market }\end{array}$ & JMIS & 2000 & $\begin{array}{l}\text { Explanation } \\
\text { and } \\
\text { prediction }\end{array}$ & $\begin{array}{l}\text { Organizational } \\
\text { behavior }\end{array}$ & Representation & $\begin{array}{l}\text { System } \\
\text { dynamics }\end{array}$ \\
\hline 2 & 37 & $\begin{array}{l}\text { Mookerjee, VS; } \\
\text { Mannino, MV; } \\
\text { Gilson, R }\end{array}$ & $\begin{array}{l}\text { Improving the } \\
\text { performance } \\
\text { stability of } \\
\text { inductive expert } \\
\text { systems under } \\
\text { input noise }\end{array}$ & ISR & 1995 & $\begin{array}{l}\text { Design and } \\
\text { action }\end{array}$ & IT artifact & Syntax & Analytical \\
\hline 2 & 38 & $\begin{array}{l}\text { Mookerjee, VS; } \\
\text { Mannino, MV }\end{array}$ & $\begin{array}{l}\text { Mean-risk trade- } \\
\text { offs in inductive } \\
\text { expert systems }\end{array}$ & ISR & 2000 & $\begin{array}{l}\text { Design and } \\
\text { action }\end{array}$ & IT artifact & Syntax & Analytical \\
\hline 2 & 39 & $\begin{array}{l}\text { Sen, S; Raghu, } \\
\text { TS; Vinze, A }\end{array}$ & $\begin{array}{l}\text { Demand } \\
\text { Heterogeneity in IT } \\
\text { Infrastructure } \\
\text { Services: Modeling } \\
\text { and Evaluation of a } \\
\text { Dynamic Approach } \\
\text { to Defining Service } \\
\text { Levels }\end{array}$ & ISR & 2009 & $\begin{array}{l}\text { Design and } \\
\text { action }\end{array}$ & IT artifact & Syntax & Analytical \\
\hline 2 & 40 & $\begin{array}{l}\text { Datta, A; Dutta, } \\
\text { K; Liang, QH; } \\
\text { VanderMeer, D }\end{array}$ & $\begin{array}{l}\text { SOA Performance } \\
\text { Enhancement } \\
\text { Through XML } \\
\text { Fragment Caching }\end{array}$ & ISR & 2012 & $\begin{array}{l}\text { Design and } \\
\text { action }\end{array}$ & IT artifact & Syntax & Analytical \\
\hline
\end{tabular}


Table B1. Restricted dataset in top-tier journals after screening procedure

\begin{tabular}{|c|c|c|c|c|c|c|c|c|c|}
\hline 2 & 41 & $\begin{array}{l}\text { Kumar, A; van } \\
\text { der Aalst, WMP; } \\
\text { Verbeek, EMW }\end{array}$ & $\begin{array}{l}\text { Dynamic work } \\
\text { distribution in } \\
\text { workflow } \\
\text { management } \\
\text { systems: How to } \\
\text { balance quality and } \\
\text { performance }\end{array}$ & JMIS & 2001 & $\begin{array}{l}\text { Design and } \\
\text { action }\end{array}$ & IT artifact & Syntax & Analytical \\
\hline 2 & 42 & $\begin{array}{l}\text { Chiang, IR; } \\
\text { Mookerjee, VS }\end{array}$ & $\begin{array}{l}\text { A fault threshold } \\
\text { policy to manage } \\
\text { software } \\
\text { development } \\
\text { projects }\end{array}$ & ISR & 2004 & $\begin{array}{l}\text { Explanation } \\
\text { and } \\
\text { prediction }\end{array}$ & IT artifact & Syntax & Analytical \\
\hline 2 & 43 & $\begin{array}{l}\text { Chen, ANK; } \\
\text { Edgington, TM }\end{array}$ & $\begin{array}{l}\text { Assessing value in } \\
\text { organizational } \\
\text { knowledge } \\
\text { creation: } \\
\text { Considerations for } \\
\text { knowledge workers }\end{array}$ & MISQ & 2005 & $\begin{array}{l}\text { Explanation } \\
\text { and } \\
\text { prediction }\end{array}$ & IT artifact & Syntax & Analytical \\
\hline 2 & 44 & Port, D; Bui, T & $\begin{array}{l}\text { Simulating mixed } \\
\text { agile and plan- } \\
\text { based requirements } \\
\text { prioritization } \\
\text { strategies: proof-of- } \\
\text { concept and } \\
\text { practical } \\
\text { implications }\end{array}$ & EJIS & 2009 & $\begin{array}{l}\text { Explanation } \\
\text { and } \\
\text { prediction }\end{array}$ & IT artifact & Syntax & Analytical \\
\hline 2 & 45 & $\begin{array}{l}\text { Gupta, A; Jukic, } \\
\text { B; Stahl, DO; } \\
\text { Whinston, AB }\end{array}$ & $\begin{array}{l}\text { An Analysis of } \\
\text { Incentives for } \\
\text { Network } \\
\text { Infrastructure } \\
\text { Investment Under } \\
\text { Different Pricing } \\
\text { Strategies }\end{array}$ & ISR & 2011 & $\begin{array}{l}\text { Explanation } \\
\text { and } \\
\text { prediction }\end{array}$ & IT artifact & Syntax & Analytical \\
\hline 2 & 46 & $\begin{array}{l}\text { Kumar, RL; Park, } \\
\text { S; Subramaniam, } \\
\text { C }\end{array}$ & $\begin{array}{l}\text { Understanding the } \\
\text { value of } \\
\text { countermeasure } \\
\text { portfolios in } \\
\text { information } \\
\text { systems security }\end{array}$ & JMIS & 2008 & $\begin{array}{l}\text { Explanation } \\
\text { and } \\
\text { prediction }\end{array}$ & IT artifact & Syntax & Analytical \\
\hline 2 & 47 & $\begin{array}{l}\text { Konana, P; } \\
\text { Gupta, A; } \\
\text { Whinston, AB }\end{array}$ & $\begin{array}{l}\text { Integrating user } \\
\text { preferences and } \\
\text { real-time workload } \\
\text { in information } \\
\text { services }\end{array}$ & ISR & 2000 & $\begin{array}{l}\text { Design and } \\
\text { action }\end{array}$ & $\begin{array}{l}\text { Individual } \\
\text { behavior }\end{array}$ & Syntax & $\begin{array}{l}\text { System } \\
\text { dynamics }\end{array}$ \\
\hline 2 & 48 & Hosanagar, K & $\begin{array}{l}\text { Usercentric } \\
\text { Operational } \\
\text { Decision Making in } \\
\text { Distributed } \\
\text { Information } \\
\text { Retrieval }\end{array}$ & ISR & 2011 & $\begin{array}{l}\text { Design and } \\
\text { action }\end{array}$ & $\begin{array}{l}\text { Individual } \\
\text { behavior }\end{array}$ & Syntax & Analytical \\
\hline 3 & 49 & $\begin{array}{l}\text { Rao, Hr; } \\
\text { Chaudhury, A; } \\
\text { Chakka, M }\end{array}$ & $\begin{array}{l}\text { Modeling Team } \\
\text { Processes - Issues } \\
\text { And A Specific } \\
\text { Example }\end{array}$ & ISR & 1995 & Explanation & $\begin{array}{l}\text { Individual } \\
\text { behavior }\end{array}$ & Adaptation & Agent based \\
\hline 3 & 50 & $\begin{array}{l}\text { Chang, RM; Oh, } \\
\text { W; Pinsonneault, } \\
\text { A; Kwon, D }\end{array}$ & $\begin{array}{l}\text { A Network } \\
\text { Perspective of } \\
\text { Digital Competition } \\
\text { in Online } \\
\text { Advertising } \\
\text { Industries: A } \\
\text { Simulation-Based } \\
\text { Approach }\end{array}$ & ISR & 2010 & Explanation & $\begin{array}{l}\text { Individual } \\
\text { behavior }\end{array}$ & Adaptation & Agent based \\
\hline
\end{tabular}


Table B1. Restricted dataset in top-tier journals after screening procedure

\begin{tabular}{|c|c|c|c|c|c|c|c|c|c|}
\hline 3 & 51 & Nan, N & $\begin{array}{l}\text { Capturing Bottom- } \\
\text { Up Information } \\
\text { Technology Use } \\
\text { Processes: A } \\
\text { Complex Adaptive } \\
\text { Systems Model }\end{array}$ & MISQ & 2011 & Explanation & $\begin{array}{l}\text { Individual } \\
\text { behavior }\end{array}$ & Adaptation & Agent based \\
\hline 3 & 52 & $\begin{array}{l}\text { Raghu, TS; } \\
\text { Jayaraman, B; } \\
\text { Rao, HR }\end{array}$ & $\begin{array}{l}\text { Toward an } \\
\text { integration of } \\
\text { agent- and activity- } \\
\text { centric approaches } \\
\text { in organizational } \\
\text { process modeling: } \\
\text { Incorporating } \\
\text { incentive } \\
\text { mechanisms }\end{array}$ & ISR & 2004 & Explanation & $\begin{array}{l}\text { Individual } \\
\text { behavior }\end{array}$ & Representation & Agent based \\
\hline 3 & 53 & $\begin{array}{l}\text { Jones, JL; Easley, } \\
\text { RF; Koehler, GJ }\end{array}$ & $\begin{array}{l}\text { Market } \\
\text { segmentation } \\
\text { within consolidated } \\
\text { E-markets: A } \\
\text { generalized } \\
\text { combinatorial } \\
\text { auction approach } \\
\end{array}$ & JMIS & 2006 & Explanation & $\begin{array}{l}\text { Individual } \\
\text { behavior }\end{array}$ & Representation & Agent based \\
\hline 3 & 54 & Curseu, PL & $\begin{array}{l}\text { Emergent states in } \\
\text { virtual teams: a } \\
\text { complex adaptive } \\
\text { systems perspective }\end{array}$ & JIT & 2006 & Explanation & $\begin{array}{l}\text { Individual } \\
\text { behavior }\end{array}$ & Adaptation & $\begin{array}{l}\text { System } \\
\text { dynamics }\end{array}$ \\
\hline 3 & 55 & $\begin{array}{l}\text { Nan, N; } \\
\text { Johnston, EW }\end{array}$ & $\begin{array}{l}\text { Using Multi-Agent } \\
\text { Simulation to } \\
\text { Explore the } \\
\text { Contribution of } \\
\text { Facilitation to GSS } \\
\text { Transition }\end{array}$ & JAIS & 2009 & Explanation & $\begin{array}{l}\text { Organizational } \\
\text { behavior }\end{array}$ & Adaptation & Agent based \\
\hline 3 & 56 & $\begin{array}{l}\text { Bichler, M; } \\
\text { Shabalin, P; } \\
\text { Pikovsky, A }\end{array}$ & $\begin{array}{l}\text { A Computational } \\
\text { Analysis of Linear } \\
\text { Price Iterative } \\
\text { Combinatorial } \\
\text { Auction Formats }\end{array}$ & ISR & 2009 & Analysis & $\begin{array}{l}\text { Individual } \\
\text { behavior }\end{array}$ & Representation & Agent based \\
\hline 3 & 57 & $\begin{array}{l}\text { Walden, EA; } \\
\text { Browne, GJ }\end{array}$ & $\begin{array}{l}\text { Sequential } \\
\text { Adoption Theory: A } \\
\text { Theory for } \\
\text { Understanding } \\
\text { Herding Behavior } \\
\text { in Early Adoption } \\
\text { of Novel } \\
\text { Technologies }\end{array}$ & JAIS & 2009 & Explanation & $\begin{array}{l}\text { Individual } \\
\text { behavior }\end{array}$ & Syntax & $\begin{array}{l}\text { System } \\
\text { dynamics }\end{array}$ \\
\hline 3 & 58 & $\begin{array}{l}\text { Kwon, D; Oh, W; } \\
\text { Jeon, S }\end{array}$ & $\begin{array}{l}\text { Broken ties: The } \\
\text { impact of } \\
\text { organizational } \\
\text { restructuring on } \\
\text { the stability of } \\
\text { information- } \\
\text { processing } \\
\text { networks }\end{array}$ & JMIS & 2007 & Explanation & $\begin{array}{l}\text { Organizational } \\
\text { behavior }\end{array}$ & Syntax & $\begin{array}{l}\text { System } \\
\text { dynamics }\end{array}$ \\
\hline 3 & 59 & $\begin{array}{l}\text { Clemons, EK; Gu, } \\
\text { B; Lang, KR }\end{array}$ & $\begin{array}{l}\text { Newly vulnerable } \\
\text { markets in an age } \\
\text { of pure information } \\
\text { products: An } \\
\text { analysis of Online } \\
\text { music and Online } \\
\text { news }\end{array}$ & JMIS & 2002 & Analysis & $\begin{array}{l}\text { Organizational } \\
\text { behavior }\end{array}$ & Syntax & $\begin{array}{l}\text { System } \\
\text { dynamics }\end{array}$ \\
\hline 3 & 60 & $\begin{array}{l}\text { Cappiello, C; } \\
\text { Francalanci, C; } \\
\text { Pernici, B }\end{array}$ & $\begin{array}{l}\text { Time-related } \\
\text { factors of data } \\
\text { quality in } \\
\text { multichannel } \\
\text { information } \\
\text { systems }\end{array}$ & JMIS & 2003 & Explanation & IT artifact & Syntax & Analytical \\
\hline
\end{tabular}

